\title{
Spatial disaggregation of tick occurrence and ecology at a local scale as a preliminary step for spatial surveillance of tick-borne diseases: general framework and health implications in Belgium
}

\author{
Valerie Obsomer ${ }^{1,2^{*}}$, Marc Wirtgen ${ }^{3}$, Annick Linden ${ }^{3}$, Edwin Claerebout ${ }^{4}$, Paul Heyman ${ }^{5}$, Dieter Heylen ${ }^{6}$, \\ Maxime Madder ${ }^{7,8}$, Jo Maris ${ }^{9}$, Maude Lebrun ${ }^{10}$, Wesley Tack $^{11}$, Laetitia Lempereur ${ }^{12}$, Thierry Hance ${ }^{2}$ \\ and Georges Van Impe ${ }^{2}$
}

\begin{abstract}
Background: The incidence of tick-borne diseases is increasing in Europe. Sub national information on tick distribution, ecology and vector status is often lacking. However, precise location of infection risk can lead to better targeted prevention measures, surveillance and control.

Methods: In this context, the current paper compiled geolocated tick occurrences in Belgium, a country where tick-borne disease has received little attention, in order to highlight the potential value of spatial approaches and draw some recommendations for future research priorities.

Results: Mapping of 89,289 ticks over 654 sites revealed that ticks such as Ixodes ricinus and Ixodes hexagonus are largely present while Dermacentor reticulatus has a patchy distribution. Suspected hot spots of tick diversity might favor pathogen exchanges and suspected hot spots of I. ricinus abundance might increase human-vector contact locally. This underlines the necessity to map pathogens and ticks in detail. While I. ricinus is the main vector, I. hexagonus is a vector and reservoir of Borrelia burgdorferi s.l, which is active the whole year and is also found in urban settings. This and other nidiculous species bite humans less frequently, but seem to harbour pathogens. Their role in maintaining a pathogenic cycle within the wildlife merits investigation as they might facilitate transmission to humans if co-occurring with I. ricinus. Many micro-organisms are found abroad in tick species present in Belgium. Most have not been recorded locally but have not been searched for. Some are transmitted directly at the time of the bite, suggesting promotion of tick avoidance additionally to tick removal.
\end{abstract}

Conclusion: This countrywide approach to tick-borne diseases has helped delineate recommendations for future research priorities necessary to design public health policies aimed at spatially integrating the major components of the ecological cycle of tick-borne diseases. A systematic survey of tick species and associated pathogens is called for in Europe, as well as better characterisation of species interaction in the ecology of tick-borne diseases, those being all tick species, pathogens, hosts and other species which might play a role in tick-borne diseases complex ecosystems.

Keywords: Tick, Vector, Spatial distribution, Ecology, Vector-borne diseases

\footnotetext{
* Correspondence: valerie.obsomer@uclouvain.be

'Université Catholique de Louvain, Earth and Life Institute, Georges Lemaitre climate and earth research centre, place Louis Pasteur 3, 1348, Louvain la Neuve, Belgium

${ }^{2}$ Biodiversity department ELIB, Université Catholique de Louvain, Earth and

Life Institute, 4 place Croix du sud, 1348, Louvain-la-Neuve, Belgium

Full list of author information is available at the end of the article
} 


\section{Background}

The incidence of tick-borne diseases is increasing in Europe [1] and follows an increase in the number of tick bites [2] attributed to two factors: abundance of questing ticks and human exposure to ticks [3]. Measures targeting human exposure by promoting timely removal of ticks failed to stop the rise in Lyme borreliosis incidence in the Netherlands. On the other hand, this rise was related to an increase in Ixodes ricinus abundance [3]. Knowing the local variations in the distribution of the species interacting in tick-borne diseases systems, including ticks, pathogens and species influencing the presence and abundance of ticks and pathogens, could provide new opportunities to estimate potential infection risks locally, identify local hot spots and develop targeted prevention, surveillance and control.

Necessary information is lacking at national and sub national levels in many countries. The first missing information concerns the presence and distribution of tick species. Efforts to characterise tick distribution on a European scale [4-6] are limited by the information available at sub national level and only target major vectors such as I. ricinus. Other tick species less willingly biting humans sometimes harbour high pathogen prevalence's and might contribute locally to the pathogens' cycles [7]. The role of all tick species present should be investigated jointly per pathogen and their distribution clarified. The second missing information concerns the spatial distribution of hosts, predators and species influencing tick populations and pathogens' prevalence in ticks. The presence and abundance of tick species varies locally according to many factors, including host availability [3]. Pathogen prevalence in ticks also varies locally according to availability of reservoirs, dead-end hosts and vectors [8]. The third set of missing information concerns pathogens associated to ticks, their presence, reservoirs, vectors and distribution. Pathogens found using classical PCR methods are those searched for, while others might be present but undetected. Because microorganisms are increasingly found in ticks, a more systematic approach is needed. The list of micro-organisms found locally or abroad in local tick species could be narrowed by clarifying pathogenicity, vector capacity and presence of reservoirs to provide a list of potential pathogens to investigate locally. This would clarify the spectrum of pathogens potentially transmitted locally through a tick bite.

In this paper, occurrence records and information on tick species relevant for public health have been compiled for a country where tick-borne diseases received little attention. In Belgium, the limited quality of current information is obvious because of proximity to the Netherlands, a country that stands out for efficient investigations of tick-borne diseases. In the Netherlands, tick bites are subject to spatial monitoring [9]. Lyme borreliosis is monitored by physician surveys targeting
Erythema migrans, the most common symptom [2]. In Belgium, only Lyme borreliosis is regularly diagnosed. In 2009, official numbers of cases varied from 500 to 1500 [10] or 9000 cases [11] according to the source. In the Netherlands, 22000 cases were recorded for that same year [2]. I. ricinus is believed to occur in Southeast Belgium but records occur elsewhere. Detailed distribution can approximate local exposure to ticks. This is of direct public health interest because according to European guidelines for Lyme borreliosis, an individual presenting an Erythema migrans is considered a confirmed case if potentially exposed to areas favourable for vector ticks [12]. Laboratory confirmation and remembering a tick bite are not necessary to confirm this diagnosis.

This study aims to show how an integrated spatial approach on tick species in a given country can provide the preliminary information needed for adapted national public health policies by providing: 1) a list of tick species present and their detailed distribution, 2) the micro-organisms they could harbour, 3) ecological traits influencing vector status, 4) implications for public health and suggestions for future research priorities.

\section{Methods}

Three sources of tick locations were considered: new tick collections, literature collections and "grey datasets". Quality levels are proposed for each record to document for example accuracy of tick location according to type of host/vegetation (lower if captured on moving animals such as dog or deer). Information on localisation, collection, vegetation or host, pathogen load, and original data source were compiled in an excel database (Additional file 1). A systematic literature search was made based on ISI web of knowledge using the keywords "tick AND ecology" from 1989 to 2001 and "tick" from 2002 to 2011. Additional articles resulted from a specific search on presence and pathogenicity of microorganisms found in ticks. The database and additional literature articles form the basis for this paper and are examined for the following items: geographical distribution, species behaviour, ecology, presence of micro-organisms. Consequences for public health and prevention are highlighted. For some sites additional details were provided by authors, however, the methodology is already described in published articles and summarised in the Additional file 1. This includes (1) Collection BAYER, 579 sites [13], (2) Collection RLVBD, 51 sites [14], (3) Collection UGENT FOREST, 33 sites [15,16], (4) Collection ARSIA, 17 sites [17], (5) Collection UCLIREC, 5 sites [18], and (6) Collection UA1, 16 sites [7,19-22]. Collection GREY DATA includes tick field observations from the website of NATAGORA and NATUURPUNT (www. observations.be, www.waarnemingen.be) by registered users involved with nature related activities from 1980 
until February 2012. Methodologies for original tick collections are described in detail below:

\section{Collection VANIMPE}

In the framework of the convention 5284a funded by IRSIA (Institut pour l'encouragement de la recherche dans l' industrie et l'agriculture), the center of acarology (UCL) led two collection campaigns in the Campine, the plateau brabançon and the Condroz. The regions were selected based on local Lyme borreliosis cases and favourable tick habitat. The first campaign in 1989 targeted 30 sites and the second campaign prospected 234 sites from May to October 1990 including 79 days of prospection. Ticks were collected from the environment by flagging. Each collection lasted 2 hours and UTM coordinates were checked on maps $(100 \mathrm{~m})$.

\section{Collection WILDSCREEN}

From 2007 to 2009, ticks from wild cervids (Cervus elaphus and Capreolus capreolus) found dead, hunted or killed for sanitary reasons were collected by the Wild Screen Network disease monitoring activities in Southern Belgium [23]. Ticks were preserved in 70\% ethanol at room temperature, and morphologically identified up to stage and species level (by L. Lempereur and A. Nahayo). Sex and repletion were recorded. Dermacentor reticulatus was also collected on wild cervids from 2010 to 2012. As D. reticulatus and D. marginatus may show overlapping phenotypes [24], a PCR was used for confirmation, targeting the Dermacentor second Internal Transcribed Spacer 2 (ITS2) with the following primers: ITS_forward (5'-GTG-CGT-CCG-TCG-ACTCGT-TTT-GA-3') and ITS_reverse (5'-ACG-GCG-GACTAC-GAC-GGA-ATG-C-3') [25]. The DNA purification was carried out using the NucleoSpin tissue kit for tissue protocol (Macherey-Nagel GmbH, Germany). Samples were frozen in liquid nitrogen and homogenized on a Tissue Lyser (Qiagen, GmbH, Germany). PCR conditions were as follow: each reaction was carried out in $50 \mu \mathrm{L}$ volume containing $4 \mu \mathrm{l}$ of the DNA preparation, $5 \mu \mathrm{l}$ of each $2 \mathrm{mM}$ dNTP, $2 \mu \mathrm{l}$ of each $10 \mu \mathrm{M}$ oligonucleotide primer, $2 \mathrm{U}$ of TaqDNA polymerase (New England Bio labs) with $5 \mu \mathrm{l}$ of the 10x PCR supplied buffer and completed to $50 \mu \mathrm{l}$ with sterile water. PCR was achieved with an initial denaturation cycle at $95^{\circ} \mathrm{C}$ for $5 \mathrm{~min}$, followed by 35 cycles $\left(94^{\circ} \mathrm{C}\right.$, $45 \mathrm{~s})$, annealing $\left(53^{\circ} \mathrm{C}, 45 \mathrm{~s}\right)$, extension $\left(72^{\circ} \mathrm{C}, 70 \mathrm{~s}\right)$ and a final extension step at $72^{\circ} \mathrm{C}$ for $10 \mathrm{~min}$. All ITS2 PCR products were sequenced using a modified Sanger method with the Big Dye terminator kit version 3.1 and resolved with a 3730 ABI capillary sequencer (Applied Bio systems). Sequencing reaction was performed with the same primers as for the PCR and sequences aligned by BLAST search.

\section{Collection ITG}

Ticks were collected by flagging for several years (site 1, $60,172)$.

\section{Collection IRSNB}

Additional tick locations registered in museum collections were provided by the IRSNB (Institut Royal des Sciences Naturelles de Belgique).

\section{Collection DGZ}

While investigating anaplasmosis in 11 farms in Flanders, in 2011, the Dierengezonheidzorg (DGZ - Animal Health Care Flanders, Belgium) recorded $I$. ricinus ticks on several animals from those 11 farms.

\section{Collection GLAXOSMITHKLINE}

Ticks were captured by flagging in 1999 in 3 sites in Belgium (sites 228, 242, 353).

\section{Collection MARTIN}

D. reticulatus was found on a human around Namur and a trypanosome discovered in the intestine of I. ricinus in the context of other research [26].

\section{Collection UGENT VETE}

The clinic of poultry diseases of Ghent University performs diagnosis required by individuals. In this framework they recorded a tick infestation on a pigeon from Argas species, probably Argas reflexus in July 2012 near Berlaar (site 303) in the province of Antwerp.

\section{Results and discussion}

The database includes 1624 records for a total of 89,289 ticks and is summarized per collection in Table 1 . Records within $3 \mathrm{~km}$ range were grouped for the display in 654 sites. Original details are available for each record (Additional file 1) and can be visualised using Google Earth (Additional file 2). Figure 1 shows sites of occurrence for all tick species.

\section{Tick species in Belgium}

Fourteen species were recorded in Belgium and 10 additional species are suspected to be present because they were recorded in surrounding areas [27-32] (Table 2). I. ricinus (Linnaeus, 1758) and I. hexagonus (Leach 1815) are widely distributed (Figure 1). I. ricinus is found in all the provinces. I. hexagonus is also present in all provinces and is known to be more abundant than I. ricinus in specific settings such as urban gardens [33]. These species are also the easiest to catch through flagging (I. ricinus) or because they are present on pets investigated by veterinarian 
Table 1 Tick species found in Belgium per collection

\begin{tabular}{|c|c|c|c|c|}
\hline & Species & Number of species & Number of ticks & Number of records \\
\hline & Ixodes ricinus (1801/395) & & & \\
\hline & Ixodes hexagonus (634/164) & & & \\
\hline & Dermacentor reticulatus (18/5) & & & \\
\hline \multirow[t]{3}{*}{ Collection BAYER } & Rhipicephalus sanguineus (6/5) & 4 & 2264 & 577 \\
\hline & Ixodes ricinus (868/271) & & & \\
\hline & Dermacentor reticulatus (297/10) & & & \\
\hline \multirow[t]{13}{*}{ Collection GREY DATA } & Ixodes lividus (5/1) & 3 & 1170 & 282 \\
\hline & Ixodes ricinus (43150/175) & & & \\
\hline & Ixodes lividus (7/2) & & & \\
\hline & Ixodes hexagonus (792/33) & & & \\
\hline & Rhipicephalus sanguineus (97/13) & & & \\
\hline & Argas reflexus (17/7) & & & \\
\hline & Argas vespertilionis (9/3) & & & \\
\hline & Hyalomma aegyptium (26/4) & & & \\
\hline & Ixodes acuminatus (1/1) & & & \\
\hline & Ixodes arboricola (190/3) & & & \\
\hline & Ixodes canisuga $(2 / 1)$ & & & \\
\hline & Ixodes frontalis $(7 / 4)$ & & & \\
\hline & Ixodes trianguliceps (9/8) & & & \\
\hline \multirow[t]{3}{*}{ Collection LITERATURE } & Ixodes vespertilionis $(29 / 11)$ & 13 & 44,655 & 273 \\
\hline & Ixodes ricinus (5819/192) & & & \\
\hline & Ixodes hexagonus (1/1) & & & \\
\hline \multirow[t]{2}{*}{ Collection VANIMPE } & Rhipicephalus sanguineus (1/1) & 3 & 5821 & 194 \\
\hline & Ixodes ricinus (2232/87) & & & \\
\hline \multirow[t]{3}{*}{ Collection WILDSCREEN } & Dermacentor reticulatus (159/11) & 2 & 2391 & 98 \\
\hline & Ixodes ricinus (4000/8) & & & \\
\hline & Dermacentor reticulatus (66/66) & & & \\
\hline Collection ITG & Ixodes frontalis $(2 / 2)$ & 3 & 4068 & 76 \\
\hline \multirow[t]{4}{*}{ Collection RLVBD } & Ixodes ricinus (22435/45) & 1 & 22,435 & 45 \\
\hline & Ixodes ricinus (2670/5) & & & \\
\hline & Ixodes hexagonus (1/1) & & & \\
\hline & Ixodes arboricola (2790/12) & & & \\
\hline Collection UA & Ixodes lividus (18/2) & 4 & 5571 & 29 \\
\hline \multirow[t]{9}{*}{ Collection ARSIA } & Ixodes ricinus (600/17) & 1 & 600 & 17 \\
\hline & Ixodes ricinus (6/4) & & & \\
\hline & Ixodes hexagonus (4/2) & & & \\
\hline & Dermacentor reticulatus $(2 / 1)$ & & & \\
\hline & Argas vespertilionis $(5 / 1)$ & & & \\
\hline & Dermacentor reticulatus (2/1) & & & \\
\hline & Ixodes canisuga (1/1) & & & \\
\hline & Ixodes frontalis (1/1) & & & \\
\hline & Ixodes trianguliceps (1/1) & & & \\
\hline Collection IRSNB & Ixodes vespertilionis (18/4) & 9 & 38 & 15 \\
\hline Collection DGZ & Ixodes ricinus $(11 / 11)$ & 1 & 11 & 11 \\
\hline Collection GLAXOSMITHKLINE & Ixodes ricinus (167/3) & 1 & 167 & 3 \\
\hline
\end{tabular}


Table 1 Tick species found in Belgium per collection (Continued)

\begin{tabular}{lllll}
\hline & Ixodes ricinus (1/1) & & 2 & 2 \\
\cline { 2 - 3 } Collection MARTIN & Dermacentor reticulatus (1/1) & 2 & 1 & 1 \\
\hline Collection UGENT & Argas reflexus (1/1) & 14 & 89289 & 1624 \\
\hline TOTAL & & 14 & 1 \\
\hline Species collected (number of ticks per species / number of location records per species), number of species, number of ticks and number of location recorded per
\end{tabular}

collection. When the number of collected ticks is unknown the value is set to 1. (Details in Additional file 1).

surveys. Other species records are sporadic and difficult to interpret. Those records might reflect patchy distribution for ticks associated with bat habitats for example, or just lack of systematic surveys for the recently investigated $D$. reticulatus (Fabricius, 1794) [34]. The distribution of species with 20 or fewer occurrences is difficult to analyse. Areas without records are due to absence or absence of surveys, thus leading to difficulties in the interpretation of the data.

Most tick species are nidiculous and thus found mainly on hosts, nests or burrows. Off host habitats are important for $I$. ricinus and D. reticulatus which quest on the vegetation. I. ricinus is found in deciduous forests, pastures bordered by trees, hedges and bushes [35], or with tall grass and high humidity [27], vegetated sand dunes [3], pine forests [14] and city parks [36]. Contradictory definitions of $D$. reticulatus habitats exist in the literature [32] with $D$. reticulatus found in drier areas than I. ricinus [37] or in moist areas along rivers [38] or on the fringe of meadows in dry vegetation [39] and variation in abundance in similar sites [40]. Many vertebrates are parasitized by $I$. ricinus (Table 3). I. hexagonus is present on many mammals but never birds [39]. Other species seem restricted to specific hosts such as birds (I. frontalis (Panzer, 1798), I. arboricola Schulze \& Schlottke, 1930, Argas reflexus (Fabricius, 1794), I. lividus Koch, 1844), rodents (I. trianguliceps Birula, 1895, I. acuminatus Neumann, 1901), mammals (I. canisuga Johnston, 1849, D. reticulatus) or bats (Argas vespertilionis (Latreille, 1796), I. vespertilionis Koch, 1844). Rhipicephalus sanguineus (Latreille, 1806) is imported on dogs and found occasionally in houses. Hyalomma aegyptium (Linnaeus, 1758) is imported on tortoises. Names are such as revised by Barker and Murrell [41] or used by Petney el al. [32]. While seasonality might be linked to host life cycle for bat ticks, most nidiculous ticks seem active year round (Table 4). I. ricinus is more frequently recorded in spring and autumn but the decrease in summer seems to be an artefact due to vegetation stages influencing flagging efficiency [42]. Slight activity occurs in winter. $D$. reticulatus seems mainly absent on the vegetation in summer.

Co-occurrence of tick species in some sites raises the question of potential interactions with species recorded together on the same hosts [33], or their eggs found in the same shelter $[43,44]$. Sites with high diversity of tick species might be hot spots of potential micro-organism exchanges. Indeed, although ticks specific, for example, to birds rarely bite humans, they might maintain a cycle of pathogens in their host populations. Those might be picked up by the generalist species I. ricinus, and passed onto humans $[7,45]$. The possibility that co-occurring exotic and local species might facilitate establishment of exotic micro-organisms should be investigated.

\section{Microorganisms associated to tick species}

In addition to potential paralysis caused by the saliva of some female ticks, which seems very rare in Europe [46], the main impact of ticks on human health is through transmission of pathogens. Ticks acquire microorganisms through an infected meal or transovarial transmission. Micro-organisms recorded in ticks might come from a recent blood meal and presence in a tick does not mean that this tick species is a competent vector. For Ixodidae ticks feeding once per stage, the microorganisms need to survive molting and be transmitted to the next host while argasidae nymphs and adults bite repeatedly. Then, to be a pathogenic for humans, they must cause symptoms in humans. A list of 300 recorded micro-organism/tick associations is presented in Additional file 3. Some sources have a low reliability but this exhaustive list is a basis for systematic investigations and reliability of vector status and pathogenicity are compiled to propose priorities for investigations. Associations are recorded mostly outside Belgium as this was little investigated in the country. Notably, while mycoplasmas are increasingly related to ticks in the USA [47], and their prevalence is increasing throughout Europe [48,49], there are no investigations of Mycoplasma in Belgian tick species in the literature.

For ticks present in Belgium, more than 100 associations with tick-borne (suspected) pathogens have been documented (Table 5) with some recorded in Belgium (Figure 2). Pathogenic Borrelia (Borrelia burgdorferi s.S., B. valaisana, B. garinii, B. afzelii, B. spielmanii), Anaplasma phagocythophilum and suspected pathogens such as Borrelia lusitaniae and Rickettsia (R. helvetica, Rickettsia sp., $R$. massilae) seem to be present throughout the country. Transovarial transmission of some Babesia species including Babesia divergens [50], B venatorum [51], (but not B. microti) [52] occurs in I. ricinus. A Babesia belt goes from Couvin (site 212) to Verviers (site 667) and has been 


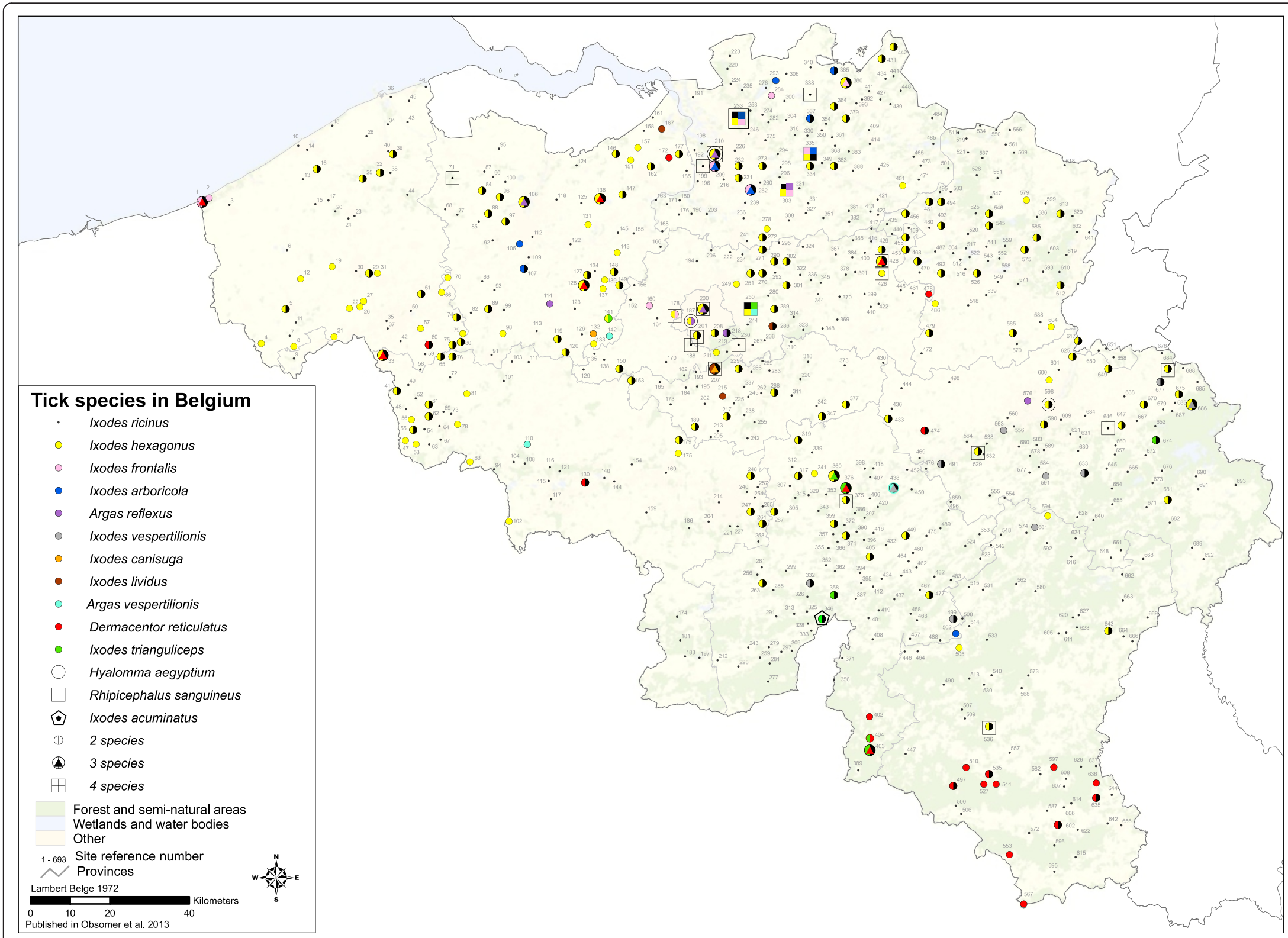

Figure 1 Map of tick species recorded in Belgium before 2011. Map of existing tick species records in Belgium. One color corresponds to one species. When two or more species occur at the same site special symbols compile the colors of the two or more species. I. ricinus is in black color. Numbers labelling each site correspond to site number in Additional file 1. 
documented for many years [53]. Other sites are based on ticks found on dogs and the place of infection is unsure, but a local focus of Babesia canis exists near Mons [54]. Some sites show a high diversity with more than 5 (suspected) pathogens. In site 575 (Genk), 481 (Ham) and 271 (Boortmeerbeek), high diversity might be linked to the presence of many ticks from many hosts. This means that (1) those localities have a higher diversity of (suspected) pathogens or (2) diversity is high everywhere but picked up there because of abundant tick material, or (3) diversity is high when ticks are abundant. Site 575 presents five pathogens (Borreliae burgdorferi s.s., B. valaisiana, B. afzelii, B. garinii and A. phagocytophilum) and three suspected pathogens (B. lusitaniae, Rickettsia helvetica and Rickettsia sp.) found in ticks collected from 38 cats (quite sedentary), thus suggesting a potential local transmission.
Most interestingly, 4 pathogens (A. phagocytophilum, $B$. burgdorferi s.s., B. afzelii, B. garinii) and two suspected pathogens (Babesia sp., Anaplasma sp.) were recorded from unfed I. ricinus nymphs (135 ticks) during flagging at site 297 (Vierves-sur-Viroin), highlighting vector status and local presence of the pathogens. This area seems to be a hot spot of I. ricinus abundance and the only place with up to 6 potential pathogens recorded in unfed questing ticks. Site 64 (Chercq) stands out with 5 cats harbouring $60 \mathrm{I}$. ricinus but no pathogens.

\section{Ecological traits influencing the potential vector role of tick species \\ The major vector I. ricinus - a generalist species}

I. ricinus is a confirmed vector for many human pathogens (Table 5). Several factors contribute to the efficiency

Table 2 Tick species of Belgium

\begin{tabular}{|c|c|c|c|c|c|c|}
\hline Tick name & Records in BE (Ticks) & Year for last record & NL & NW EU & N FR & $\overline{\mathrm{GE}}$ \\
\hline \multicolumn{7}{|l|}{ Established in the wild } \\
\hline Ixodes ricinus & $1223(88758)$ & 2011 & Yes & Yes & Yes & $\overline{\text { Yes }}$ \\
\hline Ixodes hexagonus & $201(1333)$ & 1987 & Yes & Yes & Yes & $\overline{\text { Yes }}$ \\
\hline Dermacentor reticulatus & $102(861)$ & 2012 & Yes & Yes & Yes & Yes \\
\hline Ixodes frontalis & $16(102)$ & 2011 & Yes & Yes & & $\overline{\text { Yes }}$ \\
\hline Ixodes arboricola & $15(2980)$ & 2011 & Yes & Yes & & $\overline{\text { Yes }}$ \\
\hline Ixodes lividus & $5(30)$ & 1989 & Yes & Yes & & $\overline{\text { Yes }}$ \\
\hline Ixodes canisuga & $2(3)$ & 1945 & Yes & Yes & & $\overline{\text { Yes }}$ \\
\hline Ixodes trianguliceps & $9(10)$ & 1987 & Yes & Yes & & Yes \\
\hline Ixodes acuminatus & $1(1)$ & 1987 & & Yes & & \\
\hline Argas reflexus & $8(18)$ & 2012 & Yes & Yes & & $\overline{\text { Yes }}$ \\
\hline Argas vespertilionis & $4(14)$ & 1942 & Yes & Yes & & Yes \\
\hline Ixodes vespertilionis & $15(47)$ & 1969 & Yes & Yes & & Yes \\
\hline \multicolumn{7}{|c|}{ Established in houses and recurrently imported on host } \\
\hline Rhipicephalus sanguineus & $19(104)$ & 1982 & Yes & Yes & Yes & Yes \\
\hline \multicolumn{7}{|c|}{ Not established but recurrently imported on host } \\
\hline Hyalomma aegyptium & $4(26)$ & $(1965)$ & Yes & Yes & & \\
\hline \multicolumn{7}{|c|}{ Potentially present but never found in Belgium } \\
\hline Ixodes unicavatus & Potential & Never & Yes & Yes & Maybe & No \\
\hline Ixodes uriae & Potential & Never & & Yes & Yes & Yes \\
\hline Ixodes ventalloi & Potential & Never & & Yes & Yes & \\
\hline Ixodes apronophorus & Potential & Never & Yes & Yes (UK) & & Yes \\
\hline Ixodes rugicollis & Potential & Never & & & Yes & \\
\hline Ixodes simplex & Potential & Never & & & & Yes \\
\hline Dermacentor marginatus & Potential & (1973) & & Yes & Yes & Yes \\
\hline Haemaphysalis punctata & Potential & Never & Yes & Yes (UK) & Yes & Yes \\
\hline Haemaphysalis concinna & Potential & Never & & Yes & Yes & Yes \\
\hline Haemaphysalis inermis & Potential & Never & & Yes & Yes & \\
\hline
\end{tabular}

List of tick species in Belgium (BE), the Netherlands (NL), North Western Europe (NW EU) including the United Kingdom (UK), North France (N FR) and Germany (GE). Number of records in BE (Total numbers collected include available records for larvae, nymphs and adult stages). Some collectors, however, do not collect the larvae even if they are present. The year of the last records is in brackets if only found on hosts from import. Other species are present in surrounding countries but were not considered because they are very rare (Rhipicephalus bursa, Amblyoma variegatum) or specific to host species rare in Belgium (Ixodes unicavatus, Ixodes rotchildi, Ixodes caledonicus, Ornithodoros maritimus). 
host

1. ricinus Canis lupus familiaris, Felis silvestris catus, Erinaceus europaeus, Bos taurus, Homo sapiens, Capreolus capreolus, Carduelis chloris, Cervus elaphus, Parus major, Cyanistes caeruleus, Anthus pratensis, Anthus trivialis, Apodemus sylvaticus, Clethrionomys glareolus, Erithacus rubecula Hippolais icterina, Sturnus vulgaris, Talpea europaea, Turdus ericetorum, Phylloscopus erolius, Turdus pilaris, Turdus merula, Phylloscopus inornatus, Turdus iliacus, Sitta europea, Ficedula hypoleuca, Fringilla coelebs, Lacerta vivipara, Bubo bubo

\section{off hostOOff}

Plant species: Fagus sylvatica, Carpinus betulus(hornbeam), Betula pendula (birch), Quercus robur (oak). Quercus petraea (oak). Castanea sativa, Anemone nemorosa, Convallaria majalis, Prunus padus, Pteridium aquilinum, Athyrium filix-femina, Calamagrostis epigejos, Calluna vulgaris, Cytisus scoparius, Dryopteris filix-mas, Sorbus aucuparia, Cytisus scoparius, Holcus lanatus, Holcus mollis, Juncus effusus, Molinia caerulea, Persicaria hydropiper, Urtica dioica, Acer pseudoplatanus, Convallaria majalis, Maianthemum bifolium, Carpinus sp.., Corylus avellana, Cerasus sp, Sambucus nigra, Crataegus monogyna, Vaccinium myrtillus / Pinus, Hedera helix, Rubus fructicosus, Quercus robur \& Carpinus sp., Molinia caerulea

Soils: loam or silt with limestone, clay and limestone or schists, leaf litter, schist in Famenne, limestone from Givet, sandstone, poor acid sandy soils, siliceous rock nettles, impermeable clay soils

Habitat: grazed pasture, forest ecotone, mixed acidophilous to acidophilous oak stands, birch stand with eagle fern, grassy path, garden, urban parcs, forest, dense thicket of beech, forest secondary pine poor acid sandy soils

D. reticulatus Capreolus capreolus, Cervus elaphus, Homo sapiens, Canis lupus familiaris

Plant species: grasses, hawthorn, blackthorn (Prunus spinosa), brambles blackberry (Rubus fruticosus), birch (Betula pendula), mixture of grasses, hornbeam (Carpinus betulus), woodland (mainly Picea abies), ferns (Pteridium aquilinum), jennets (Genista scorpius), oak (Quercus robur) Habitat: Fallow land, marshland, pasture used for grazing, woodland open

\begin{tabular}{|c|c|c|}
\hline 1. hexagonus & Felis silvestris catus, Canis lupus familiaris, Ericaneus europeus, Cervus elaphus, mustela putorius & $\begin{array}{l}\text { Rabbit burrow, in herbis, in grassy nest, in house, burrow of Meles meles, endolithe nest of } \\
\text { Coloeus monedula, pasture with edges or forest, impermeable clay soils, cave, burrow of fox }\end{array}$ \\
\hline 1. canisuga & Polecat: Mustela putorius & Riparian nest \\
\hline 1. trianguliceps & Rodents, Rattus rattus, Rattus norvegicus, Apodemus sylvaticus, Clethrionomys glareolus & Burrow of rodents \\
\hline 1. acuminatus & Rodents: Apodemus sylvaticus & \\
\hline 1. frontalis & $\begin{array}{l}\text { Birds: Parus major, Turdus merula, Sylvia atricapilla, Cyanistes caeruleus, Sturnus vulgaris, Parus } \\
\text { montanus, Turdus viscivoru }\end{array}$ & It is sometimes found in understorey vegetation, experimental nest box \\
\hline 1. arboricola & Birds: Parus major, Cyanistes caeruleus, Sitta europea, Corvus monedula & $\begin{array}{l}\text { Occurs in particular in bird nests inside cavities (like tree-holes for example), nest, } \\
\text { Delichon urbica nest, experimental nest box }\end{array}$ \\
\hline 1. lividus & Birds: Riparia riparia & Riparia riparia (nest) \\
\hline R. sanguineus & Canis lupus familiaris & house \\
\hline A. reflexus & Columba livia & flat, house, dovecot \\
\hline A.. vespertilionis & Bats: Pipistrellus pipistrellus, Eptesicus serotinus, rhinocephalus hipposideros & \\
\hline I. vespertilionis & Bats: Rhinolophus hipposideros, Rhinolophus ferrumequinum, Barbastelle, Myotis myotis & Cave wall and on stalagmites \\
\hline H.aegyptium & Tortoise: Testudo graeca, Testudo mauritanica & \\
\hline
\end{tabular}


Table 4 Seasonality of tick observations (number of ticks) in Belgium

\begin{tabular}{|c|c|c|c|c|c|c|c|c|c|c|c|c|}
\hline & Jan & Feb & Mar & Apr & May & Jun & Jul & Aug & Sep & Oct & Nov & Dec \\
\hline I. ricinus & 2 & 22 & 1008 & 851 & 2333 & 1288 & 1979 & 1559 & 978 & 948 & 158 & 60 \\
\hline D. reticulatus & 150 & 12 & 1 & 2 & & & & 1 & 1 & 38 & 117 & 2 \\
\hline 1. hexagonus & 4 & & 2 & 13 & 9 & 32 & 13 & 13 & & 1 & 3 & \\
\hline 1. canisuga & & & 1 & 2 & & & & & & & & \\
\hline I. trianguliceps & 1 & & 1 & & 1 & 2 & & & & 2 & 2 & \\
\hline 1. acuminatus & & & & & 1 & & & & & & & \\
\hline 1. frontalis & & & & & 1 & & & 10 & 5 & 1 & 1 & \\
\hline 1. arboricola & 1 & 1 & & & & 196 & & & & & 1 & \\
\hline 1. lividus & & & 3 & & 13 & & 14 & & & & & \\
\hline R. sanguineus & & & & & 6 & & & 49 & & & & \\
\hline A. reflexus & & & & & & 5 & 100 & 1 & 1 & & 1 & \\
\hline A. vespertilionis & & & & 4 & & & & & & & & 3 \\
\hline I. vespertilionis & 5 & 4 & 11 & 2 & & 1 & 8 & & 2 & & & \\
\hline H. aegyptium & & & & & 22 & 2 & & & & & 2 & \\
\hline
\end{tabular}

of $I$. ricinus [55]: (1) it is the most abundant tick species in Europe with all stages readily biting humans [56]. (2) This species takes one meal on 3 different hosts in one life cycle and parasitizes a wide range of hosts from mammals (e.g. squirrels, badgers, wild boars, cervids, foxes, dogs, cats, cows, rodents, bats) to birds (common blackbird, European robin, pheasant, nest of the Eagle owl), reptiles, lizards and amphibians [57-59]. Larvae and nymphs are found on any hosts and frequently on rodents or birds $[60,61]$. Adults feed on larger mammals. A large range of hosts means that there are opportunities to encounter many pathogens and disperse in many habitats, with for example $I$. ricinus representing $20 \%$ of ticks found on Parus major [7]. (3) Phenologic plasticity is wide with all stages surviving 2 weeks under water, several ticks surviving at $-10^{\circ} \mathrm{C}$, and non engorged nymphs kept alive several months in a fridge $\left(5^{\circ} \mathrm{C}\right)$ waking up in minutes if heated by hand contact. The species is vulnerable to desiccation and will not be encountered in arid or non-vegetated environments. Temperatures over $35^{\circ} \mathrm{C}$ for two weeks will kill all stages [35]. Tolerance to desiccation can be higher in ticks infected by pathogens [62]. This species walks on average $40 \mathrm{~cm}$ around its questing post and finds shelter in litter or soil cracks [35]. While ticks interrupt questing to move down the vegetation, in order to rehydrate (quiescence), Perret et al. discovered that after dark, quiescence was often interrupted by walking events not necessarily leading to questing, with ticks walking repeatedly $9 \mathrm{~m}$. They suggested that some of these movements represent horizontal walks if the ticks were not confined to their experimental vertical channels and that some of these movements represent activities that enable ticks to find a favourable questing site in nature [63]. Similar experiments but in horizontal arenas did not record such movements [64]. I. ricinus is widely distributed in Belgium with sites of apparently higher occurrence (around sites 219, 286, 288, 374, 499) (Figure 3). Lack of standardisation impedes calculation of tick densities and tick abundance and is presented here as the total number of specimens collected in a site. While abundance is expected to decrease from East to West with decreasing forest cover, this is not what comes out of the general map. Few occurrences are recorded in the Southeast despite high forest cover, but few surveys are carried out in that region, while many surveys took place in Campine to clarify tick presence. The large abundance around the Meuse area is picked up as well as decreased abundance between the Meuse and Brussels, which corresponds to a highly cultivated area (Hesbaye). Abundance is also lower along the coast, which is intensely cultivated. High abundances are recorded along the Dutch border and might reflect an increase in tick populations such as recorded in the Netherlands. These trends need, however, to be confirmed because of the lack of standardisation in sampling.

\section{Secondary vectors $I$. hexagonus and $D$. reticulatus}

I. hexagonus is a confirmed vector of B. burgdorferi s.l. [65] with $28 \%$ prevalence recorded [66]. It is a nidiculous species found in burrows and occasionally in caves [44]. This reduces human vector contact but several characteristics must be highlighted: 1) human infestations were frequent during the war when people sheltered in underground sites during air raids [45] and I. hexagonus is considered a common parasite of man in Germany and the United Kingdom [43], 2) the species has a wide range of hosts such as hedgehogs, mustelids, foxes, 
Table 5 Tick/micro-organism associations for which pathogenic status and vector status for human should be investigated as a priority: pathogens and suspected pathogens/tick species associations found abroad or in Belgium referenced in the literature for tick species found in Belgium

\begin{tabular}{|c|c|c|c|c|c|c|c|}
\hline Tick species & $\mathrm{V} / \mathrm{U}$ & Borrelia & Babesia & Rickettsia & $\begin{array}{l}\text { Coxiella, } \\
\text { Franciscella Anaplasma }\end{array}$ & Virus & Other \\
\hline \multirow[t]{2}{*}{ I. ricinus } & $\mathrm{V}$ & $\begin{array}{l}\text { burgdorferi sensu stricto*, } \\
\text { afzelii*, garinii*, lusitaniae } \\
\text { valaisiana }^{*} \text {, spielmanii } \\
\text { bavariensis }{ }^{*}, \text { miyamoto }{ }^{*},\end{array}$ & $\begin{array}{l}\text { venatorum*, } \\
\text { divergens*, microti* }\end{array}$ & helvetica & $\begin{array}{l}\text { F. tularensis* } \\
\text { A. phagocytophilum }\end{array}$ & $\begin{array}{l}\text { CCHF*, TBEV } \\
\text { Louping III* }\end{array}$ & \\
\hline & U & ruskii & $\begin{array}{l}\text { bovis, bigemina, } \\
\text { rodhaini }\end{array}$ & $\begin{array}{l}\text { prowazekii*, conorii*, } \\
\text { slovaca*, monacensis*, }^{*} \text { felis }{ }^{*}, \text { massiliae}^{*} \text {, typhi*, sp. }\end{array}$ & C. burnetii* & $\begin{array}{l}\text { WNV*, Eyack*, } \\
\text { Erve* Tettnang*, } \\
\text { Tribec*, KEMV* }\end{array}$ & $\begin{array}{l}\text { Bartonella henselae*, Serratia marcescens*, } \\
\text { Staphylococcus aureus*, Candidatus Neoehrlichia } \\
\text { mikurensis*, Toxoplasma gondii", Pasteurella } \\
\text { pneumotropica*, Chromobacterium violaceum*, } \\
\text { Pseudomonas aeruginosa*, Diplorickettsia massilinsis }\end{array}$ \\
\hline 1. frontalis & $U$ & $\begin{array}{l}\text { afzelii }{ }^{*} \text {, garinii }{ }^{*} \text {, turdi-like } \\
\text { burgdorferi sensu lato, }\end{array}$ & & & C. burnetii* & $K E M V^{*}, T B E V^{*}$ & Candidatus Neoehrlichia mikurensis* \\
\hline 1. acuminatus & U & burgdorferi sensu lato & & & C. burnetii* F. tularensis* & Bhanja & \\
\hline \multirow[t]{2}{*}{ 1. hexagonus } & V & burgdorferi sensu lato & & & & TBEV* & \\
\hline & $U$ & $\begin{array}{l}\text { burgdorferi sensu stricto*, } \\
\text { valaisiana*, spielmanii*, garinii*, } \\
\text { afzelii*, lusitaniae, bavariensis* }\end{array}$ & microti*, bovis & conoriï, helvetica, sp. & A. phagocytophilum* & Erve & \\
\hline I. arboricola & U & $\begin{array}{l}\text { garinii }{ }^{*}, \text { valaisiana* } \\
\text { afzelii, burgdorferi sensu } \\
\text { lato, spielmanii }^{*}\end{array}$ & & helvetica, sp. & & TBEV* & \\
\hline 1. lividus & U & burgdorferi sensu stricto*, garinii* & & (heilongjiangensis), sp. & C. burnetii* & TBEV* Kama & \\
\hline 1. canisuga & U & burgdorferi sensu lato & & & & TBEV* & Yersinia pestis (Plague) * \\
\hline \multirow[t]{2}{*}{ I. trianguliceps } & V & & microti* $^{*}$ & & & & \\
\hline & $U$ & $\begin{array}{l}\text { burgdorferi sensu lato, } \\
\text { afzelii*, garinii* }\end{array}$ & & & $\begin{array}{l}\text { C. burnetii*, F. tularensis* } \\
\text { A. phagocytophilum* }\end{array}$ & $\begin{array}{l}\text { Louping-ill*, } \\
\text { TBEV* CCHF* }^{*}\end{array}$ & \\
\hline I. vespertilionis & U & & & & & Kul, TBEV* & \\
\hline \multirow[t]{2}{*}{ D. reticulatus } & V & & microti* $^{*}$ & sibirica* $^{*}$ & C. burnetii* & $O H F^{*}$ & \\
\hline & U & burgdorferi sensu lato & $\begin{array}{l}\text { divergens* } \\
\text { bigemina }\end{array}$ & $\begin{array}{l}\text { slovaka*, canada*, conorii*, } \\
\text { sp, helvetica*, raoultii* }\end{array}$ & $\begin{array}{l}\text { F. tularensis* Francisella- } \\
\text { like } \boldsymbol{A} \text {. phagocytophilum }\end{array}$ & TBEV* & Bartonella henselae* \\
\hline \multirow[t]{2}{*}{ R. sanguineus } & $\mathrm{V}$ & & & conorii* $^{*}$ & & $\mathrm{CCHF}^{*}$ & \\
\hline & U & burgdorferi sensu lato & $\begin{array}{l}\text { microti-like*, } \\
\text { gibsoni }\end{array}$ & $\begin{array}{l}\text { Candidatus rickettsia } \\
\text { kulagini, massiliae*, } \\
\text { canis, felis*, rickettsi*, } \\
\text { rhipicephali, }\end{array}$ & $\begin{array}{l}\text { C. burnetii*, } \\
\text { A. phagocytophilum* }\end{array}$ & Thogoto* & $\begin{array}{l}\text { Ehrlichia canis, Ehrlichia ewingii Hepatozoon canis, } \\
\text { Salmonella bacteria, Batonella vinsonii, Rangelia } \\
\text { vitalii, Dipetalonema dracunculoides, Mycoplasma } \\
\text { haemocanis, Leishmania infantum }\end{array}$ \\
\hline A. reflexus & U & & & & C. burnetii* & $\begin{array}{l}\text { WNV } V^{*}, T^{\prime} B V^{*}, \\
\text { NYMV, QRFV }\end{array}$ & \\
\hline A. vespertilionis & U & burgdorferi sensu lato, borrelia sp & & & C. burnetii* & $\begin{array}{l}\text { rabies*, IK (KTR), } \\
\text { SOK }\end{array}$ & Wolbachia persica, Treponoma vespertilionis \\
\hline H. aegyptium & U & turcica, sp & & & C. burnetii* & & \\
\hline
\end{tabular}

$V$ confirmed vector, $U$ unknown vector status, * recognised pathogen, WNV West Nile Virus, CCHF Crimean-Congo Hemorrhagic fever, TBEV Tick borne Encephalitis virus, QRFV Quaranfi Virus, NYMV Nyamanini virus, KTR Ketera virus, OHF Omsk Hemorrhagic fever, SOK Sokolok, IK Issyk Kul, KEMV Kemerovo. In bold pathogen recorded in Belgium. Details in Additional file 3. 
polecat, badger, roe deer [30], as well as dogs and cats which can increase the spread of ticks and import ticks in gardens close to humans, 3) I. hexagonus is found in urban gardens [33], 4) most hedgehogs are infested [67] and the presence of ticks in their surface nests is a potential threat when gardening [33], 5) This species brings pathogens to people normally not at risk for tick bites (just gardening) and can remain undetected for a longer time, 6) it is active throughout the year [68], 7) because of B. burgdorferi s.l. transovarial transmission [65], this species could maintain a silent high rate of infection creating long term foci of high infection in the wildlife in areas where it acts as reservoir, 8) finally, Lyme borreliosis could be picked up by I. ricinus sharing the same host. In Belgium, I. hexagonus is widespread on cats and dogs [13] and has been observed on many mammals (Table 3), on humans [27], in nests, burrows, caves (sites 594, 617), house (site 200) and on grass (sites 492, 670). Populations might fluctuate between years [27]. The species in Belgium carries all the pathogenic species of Borrelia burgdorferi s.l., A. phagocytophilum as well as the suspected pathogen $R$. helvetica [13].

D. reticulatus might be restricted to limited areas and not actively questing in the warm months when people are entering risky areas. D. reticulatus is reported on wild boar, cervids, dogs, horses and cats in the French Ardennes [37], wolves or rarely birds [27,32,43]. It can bite humans [69]. Adults are captured by flagging but immatures are nidiculous. This species seems to be expanding its distribution in Europe. In Belgium, the tick has probably been present for some time with one specimen recorded on vegetation in 1950 (site 553), on a dog (site 567) and a human in the eighties (site 376). Established populations have only recently been monitored. Between 2007 and 2009, 16 out of 2297 ticks taken from 161 wild cervids [23] (WILDSCREEN collection) were D. reticulatus. From 2010 until March 2012, 150 additional $D$. reticulatus were discovered on 3 cervids in 6 sites including one confirmed by flagging (site 797). Confirmation of the species at a molecular level was carried out when sequences of the $646 \mathrm{bp}$ of a part of the ITS2 gene were successfully obtained for 16 D. reticulatus. These 6 sites are in the Southeast but this tick is found on vegetation in the North $(60,130,172$, 535) [34] and on hosts in other locations [13].

\section{Ticks parasite of birds}

Birds probably carry ticks to most geographical locations but this does not mean that ticks will survive in these locations. The presence of all pathogenic species of B. burgdorferi s.l. in I. frontalis and I. arboricola in Belgium suggests a potential role in the Borrelia life cycle [7]. Up to $50 \%$ of I. frontalis [69] and also I. lividus [70] were infected with B. burgdorferi s.l. in other countries. While seldom reported as biting humans, they might maintain the pathogen cycle in wildlife. I. frontalis (previously $I$. pari) is associated with a broad range of songbirds, including thrushes (Turdidae), the Great tit and the collared dove $[7,28,43]$, with up to 30 specimens per bird [71]. I. frontalis is occasionally collected by flagging [72] and evidence suggests that it might be more often present in under-storey vegetation than in nests [7]. In Belgium it has been found on birds in 11 sites. I. arboricola is found mainly in Europe but was recorded in Egypt on birds coming back to Europe [27]. It is a nidicolous tick infesting birds and bats [73]. The Great tit might be the dominant host but heavy infestations occur on the Common starling and Peregrine falcon [32]. In Belgium it was recorded in 10 places including 3 sites with 70 specimens (sites 233, 252, 337) where the species was actively surveyed. Specimens were found on birds (Table 3) and in nests of the House martin. I. lividus is found on the Sand martin and in their nests [27]. Experimental records showed that these ticks were collected on the Great tit [74] and it was found repeatedly in nests of the House martin in Japan [75].

\section{Ticks parasite of rodents and small mammals}

Small mammals and particularly rodents are reservoirs of many diseases, but few studies have targeted ticks on rodents in Belgium. Next to I. ricinus and I. hexagonus, ticks present on rodents and small mammals include I. canisuga, I. trianguliceps and I. acuminatus. These species are carriers of some pathogens (Table 5) including B. burgdorferi s. l. [76-78] with 30\% prevalence for I. canisuga in Spain [66]. I. canisuga is part of a group of species difficult to discriminate morphologically (including I. hexagonus, I. arboricola and I. lividus) [27]. I. canisuga is widely distributed and found on half of the foxes in Northern France [30] but also on polecats, weasels, badgers, Eurasian owls, dogs and cats $[79,80]$ with up to 200 specimens reported on one dog [81]. In Great Britain, $11 \%$ of the ticks found on dogs were $I$. canisuga [80] but none were reported in a Belgian survey [13]. This nidiculous species is found in nests, burrows or rarely in caves [44] with fed females climbing upwards in crevices above ground [28]. In Belgium, only two specimens were found, on a polecat (site 132) and a nest (site 207). I. trianguliceps is found almost exclusively on micromammals including shrews and rodents, exceptionally on moles, birds or goats and very rarely on humans $[27,55]$. The tick is nidiculous but may wait for hosts on the soil surface [82]. It is commonly found in wet biotopes including moorlands, meadows, or pine, deciduous and birch forests [83]. In France, immature are found with immature of $D$. reticulatus, I. acuminatus, and $I$. ricinus on the same rodents $[84,85]$. In Belgium, I. trianguliceps is probably frequent and found on rodents in 8 sites. I. acuminatus 


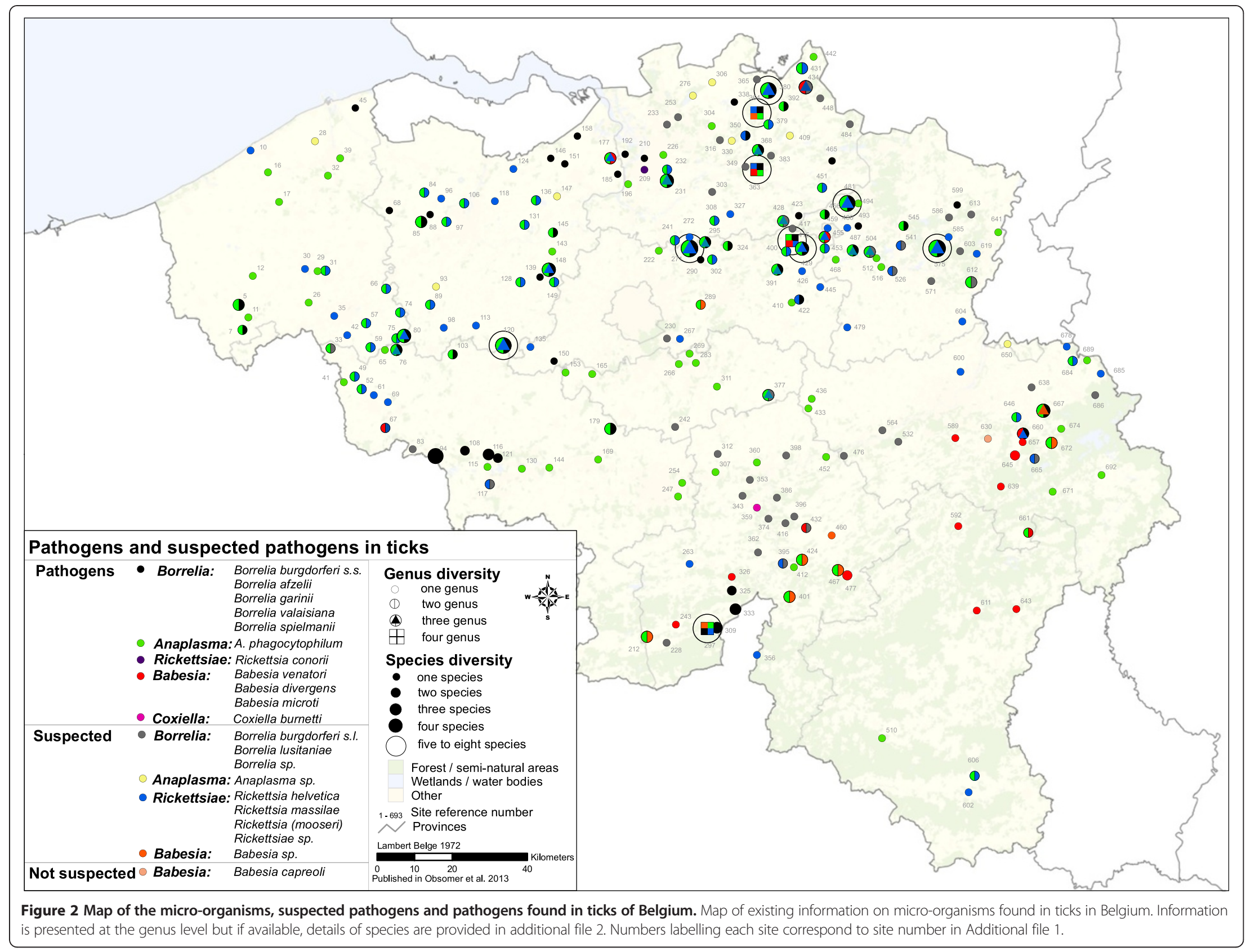


parasitizes small mammals, birds and sometimes humans and is mostly found in nests and burrows [28]. Only one specimen was found in Belgium on a wood mouse (site 630).

\section{Other tick species sharing habitats with humans}

Three tick species are not frequent but bite humans and can establish populations inside houses, making them a potential threat. Rhipicephalus sanguineus is a tropical tick imported on dogs or rarely with hares, cattles, horses, or plants [55]. The tick cannot survive outside but multiplies inside houses and dog kennels [27]. Ticks hunt for hosts by moving actively [86], can drink free water and survive for years inside. This was shown to cause house infestations in 12 cities in the Netherlands, in Switzerland [87] and 334 foci in Berlin [88]. Tick populations can build up in some years from one engorged female to thousands of ticks and eggs $[87,89,90]$. Eggs are hidden in cracks and crevices and ticks crawl around. Mean temperature probably limits its northward distribution [91]. This species is rarely found on humans [27], but seems to more willingly bite humans occasionally, representing at times up to $7 \%$ of ticks biting men [92]. Up to 22 ticks on one man were reported in France [93]. Some studies suggest that this highlights a change of behaviour related to temperature increase $[94,95]$ but this needs to be further investigated. $R$. sanguineus is a vector of highly pathogenic Rickettsiae conorii with confirmed transovarial passage [96]. Prevalence in nymphs infesting houses can reach up to $40 \%$ [87], against usually 1\% [94] outside. In Belgium, $R$. sanguineus was found in houses in Antwerp [27] (site 210), Hoboken (site 199) [90] and Maldegem (site 71), but also on dogs with a travel history (e.g. sites 338, 426, 536, 684) [13] and on humans (site 210) [27].

Argas reflexus is frequent mainly on pigeons but readily bites humans, chickens or horses in buildings in the absence of pigeons [43,55]. With Argas vespertilionis (see below) this species belongs to the Argasidae family, which differs from Ixodidae in their feeding habits. Ticks take many short meals. Nymphs and adults engorge in less than an hour. Ticks feed on eight to twelve hosts per life cycle and spend most of their life in the hosts' habitat [97]. Building infestations are undetected for years because of nocturnal host-seeking behaviour, high host specificity and short meals [98]. However, when pigeons are eradicated, A. reflexus appear seeking for alternative hosts [97]. Even if the build-up of a large number of ticks takes years, thousands of ticks were found repeatedly when investigating 188 infested buildings in Germany [98]. Searching for ticks before renovating is now a current recommendation in Germany. Particularities include a long lifetime of up to 9 years without food, low water loss rate, absorption of water vapour at
$75 \%$ relative humidity and high tolerance of temperature extremes. Movements are restricted to periods of hostseeking, the remaining time being spent resting aggregated in cracks of walls [97-99]. In Belgium ticks were recorded in 7 sites from pigeons, pigeon houses, houses and flats. The bites may cause allergy, anaphylactic shock or loss of consciousness [100]. It is an unconfirmed vector of human pathogens.

Argas vespertilionis parasitizes bats [43]. They stay the whole year in or near caves or other shelters (roofs of houses), the hosts being present or not. Eggs were found together with eggs of $I$. hexagonus and $I$. vespertilionis $[43,44]$. Ticks bite alternative hosts in the absence of their usual host and readily bite man. People reported being bitten in caves or in their bed when bats are in the attics [55]. Larvae attach for 19 days. Nymphs and adults feed in less than one hour [97]. They take many small meals on many hosts potentially accumulating pathogens. A. vespertilionis causes irritating bites on humans and viable strains of $C$. burnetii were isolated from ticks which had been dead for a year [97]. While $84 \%$ of museum specimens tested positive for B. burgdorferi s.l. in the UK [78], this might reflect sample contamination. Borrelia sp. organisms related to Borrelia recurrentis, $B$. duttonii and B. crocidurae were present in numbers in a dying bat in the UK [101] parasitized by $A$. vespertilionis. In Belgium, 11 ticks were found on hosts in four locations.

\section{Species of little interest for human health}

Ixodes vespertilionis was never recorded biting man. It parasites the Lesser horseshoe and the Great bats. It actively searches for hosts by walking slowly on very long legs in caves. It is restricted to the darkest part of the caves, offering $100 \%$ humidity $[28,102]$. Decrease of humidity to $61 \%$ increases tick activity until they die after a few hours. All stages are mainly found in caves, moving away with the host but coming back for molting and egg laying [102]. Specimens are not on the ground but on walls and roof crevices. In West France low densities are present in most caves. Ticks were found in caves or on bats in 10 sites in East Belgium [27].

\section{Conclusion}

By providing a countrywide disaggregated approach on tick-borne diseases, this study provides essential preliminary information to build up a national public health policy based on spatial surveillance of tick-borne diseases [103] and help to delineate priorities for future investigations. These are summarised in Table 6. (1) Regarding tick presence, this study highlights the lack of information about current species, and the need to search for species present in bordering regions. (2) In terms of tick distribution, occurrence data offers a useful picture, and this, 


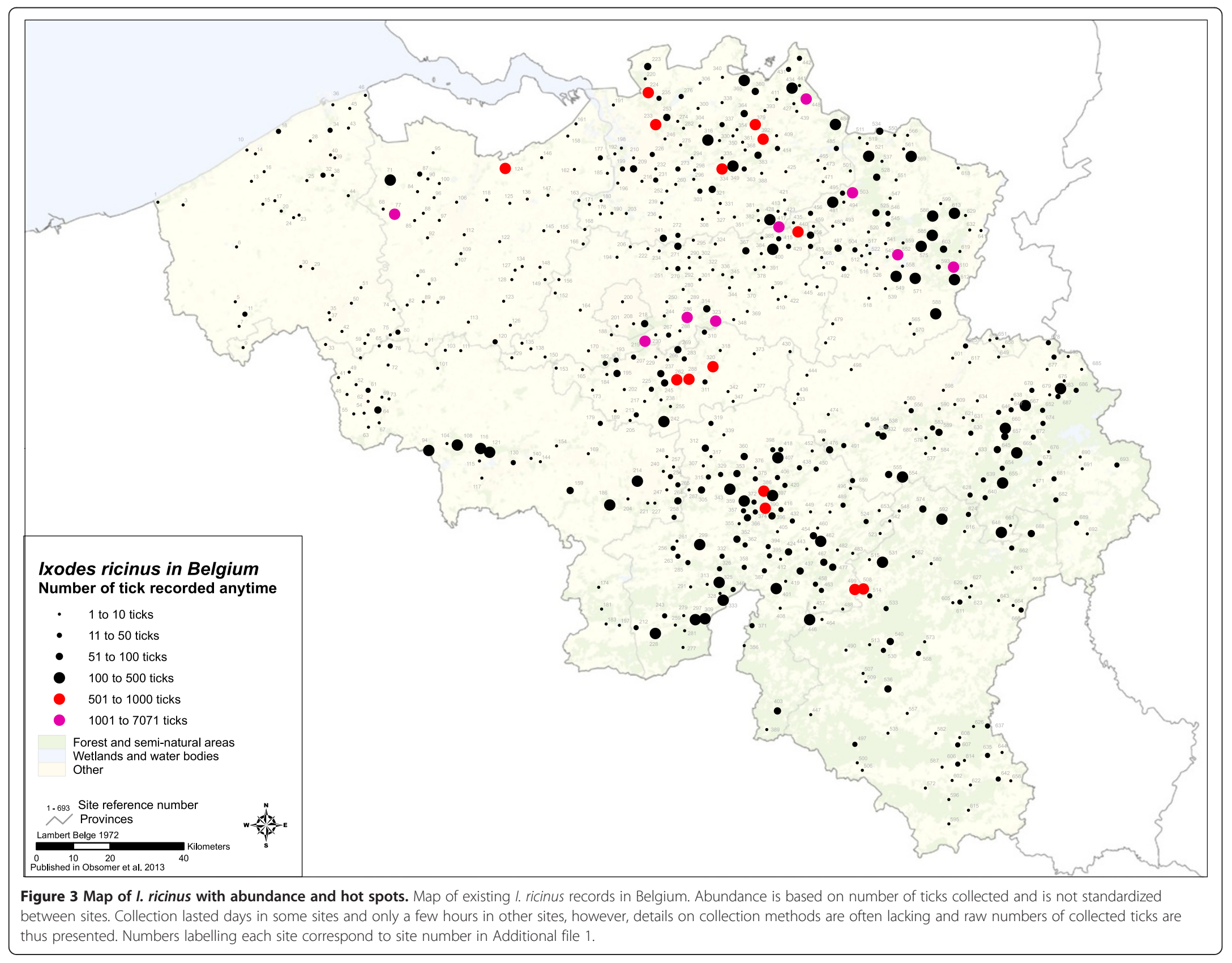


particularly if the lack of detailed distribution of major determinants (hosts, predators) impeded building of adequate distribution models. However, modelling tick distribution could provide information in places not surveyed, clarify ecology and attach local probabilities to tick presence [104]. For modelling exophilic tick distribution (I. ricinus and D. reticulatus), examples in the field of malaria vectors show that occurrences can prove useful to delineate species distribution [105]. However, models perform better when explanatory variables englobe most ecologically relevant parameters [106]. Because of their influence on ticks and on the pathogens presence and abundance, distribution of relevant host species or valuable proxies [3] should be integrated in the models with major habitat characteristics. Distribution of nidiculous species could be approached by mapping their specific hosts. (3) Because of the above, the potential roles (hosts, pathogen reservoir versus accidental host [107], influencing tick abundance, influencing pathogen prevalence, and predators) of the birds, mammals, reptiles, amphibian or other local species should be assessed and their distribution investigated. (4) With regards to pathogens, their presence needs to be clarified. The list of micro-organisms /tick associations provided here needs to be narrowed by investigating pathogenicity, identifying reservoirs (ticks and other species), selecting pathogens for which reservoirs are present, and identifying vector capacity for associated ticks. (5) With regards to pathogen distribution, pathogens should be monitored in ticks, reservoirs or any hosts to provide a spatial distribution per pathogen. (6) Human vector contact could be approached using public knowledge from groups at risk, such as nature lovers, hunters, foresters, veterinarians, health practitioners or even the general public. Such facilities for recording tick bites were developed successfully in the Netherlands [9]. (7) Finally a risk map should provide the following locally: integration of the above distribution maps to determine the probability of being bitten by a tick, to obtain an

Table 6 Main findings and suggestions for further research priorities

\begin{tabular}{|c|c|c|}
\hline & Current knowledge & Suggestions for future research priorities \\
\hline Tick presence & $\begin{array}{l}\text {-The current national list of occurring tick species } \\
\text { (not previously available) }\end{array}$ & $\begin{array}{l}\text { - Search for tick species recorded in neighbouring countries } \\
\text { country (targeting prefered host species or habitat) }\end{array}$ \\
\hline \multirow[t]{3}{*}{ Tick distribution } & $\begin{array}{l}\text { - A first distribution map for Ixodes ricinus based on occurrences } \\
\text { which highlights presence of the species in all the provinces }\end{array}$ & $\begin{array}{l}\text { - Build up a distribution model for exophilic species such as Ixodes } \\
\text { ricinus and Dermacentor reticulatus based on habitat preferences } \\
\text { and distribution of other influencing species }\end{array}$ \\
\hline & $\begin{array}{l}\text { - Current very partial knowledge of distribution for } \\
\text { the other tick species }\end{array}$ & $\begin{array}{l}\text { - Build up a distribution model for nidiculous species based on } \\
\text { distribution of major host species }\end{array}$ \\
\hline & & - Perform a systematic tick survey across the country \\
\hline \multirow[t]{2}{*}{ Tick hosts/ reservoirs } & $\begin{array}{l}\text { - Provide for each tick a list of hosts on which they } \\
\text { have been recorded in the country }\end{array}$ & $\begin{array}{l}\text { - For each local vertebrate species check potential host } \\
\text { status for each tick species or potential influence } \\
\text { on tick population }\end{array}$ \\
\hline & & - Map the distribution of relevant species \\
\hline \multirow[t]{4}{*}{$\begin{array}{l}\text { Presence of } \\
\text { pathogens }\end{array}$} & $\begin{array}{l}\text { - Potential presence of pathogens such as Borrelia } \\
\text { burgdoferi s.l. in many tick species }\end{array}$ & - Check the pathogenicity of each micro-organisms species \\
\hline & $\begin{array}{l}\text { - List of microorganisms potentially present locally } \\
\text { or aborad in local ticks species }\end{array}$ & $\begin{array}{l}\text { - For pathogenic microorganisms check vector status of } \\
\text { associated ticks Identify presence of potential reservoirs } \\
\text { for pathogens (tick hosts) }\end{array}$ \\
\hline & - List of tick/ micro-organisms associations & $\begin{array}{l}\text { - Investigate pathogen distribution across species } \\
\text { to better comprehend }\end{array}$ \\
\hline & & - risk before modelling risk map \\
\hline \multirow[t]{2}{*}{ Pathogen distribution } & - First map of (suspected) pathogens found in ticks & - Search for additional pathogens in ticks of the country \\
\hline & & $\begin{array}{l}\text { - Make a pathogen distribution map } \\
\text { (found in ticks, hosts, reservoirs) }\end{array}$ \\
\hline Human-vector contact & & $\begin{array}{l}\text { - Use public knowledge from nature defense group, scouts, } \\
\text { veterinary, general practitioner to localise and quantify tick bites }\end{array}$ \\
\hline \multirow[t]{3}{*}{$\begin{array}{l}\text { Tick-borne } \\
\text { diseases risk map }\end{array}$} & $\begin{array}{l}\text { - Some hot spot with highest I. ricinus abundance are } \\
\text { highlighted but because of unreliable sampling those } \\
\text { should be further investigated }\end{array}$ & - Investigate presence and prevalence of pathogenic species \\
\hline & & $\begin{array}{l}\text { - Make a countrywide standardised survey to allow } \\
\text { comparing abundance between sites. }\end{array}$ \\
\hline & & $\begin{array}{l}\text { - In a given area, what is the probability 1) to get a tick bite, } \\
\text { 2) that this tick was infected with pathogens } \\
\text { 3) infected by which pathogen(s) }\end{array}$ \\
\hline
\end{tabular}


infected tick bite per pathogen, and a list of potential pathogens locally. In this context, potential hotspots could be identified as well as places needing further investigation. This would provide a spatial disaggregation of risk and prepare analysis of seasonal or yearly variations.

I. ricinus is the main vector of diseases in Belgium because it is present in most vegetated areas, carries many pathogens and is responsible for most tick bites in humans. Its distribution highlights the possibility of becoming infected by the pathogenic agent of Lyme borreliosis in any province. Other species might play a role by maintaining pathogens present in wildlife, or by bringing pathogens closer to people in their houses and gardens. While the number of bites on humans caused by other species is less than by I. ricinus, occurrence of such an event in unexpected areas such as houses or gardens or during the winter season extends the risk to people not considered to be at risk and increases the probability of a tick bite being ignored. Some places seem to pose a greater risk with more abundant tick populations, higher diversity of pathogens or both, but this should be confirmed. Current prevention measures target B. burgdorferi s.l. mainly through deticking. Other pathogens are increasingly investigated and found in domestic animals, wildlife or humans and transmission of some of those can occur at the time of the tick bite without delay (e.g. TBEV). Avoidance behaviour should be promoted such as avoiding areas with ferns [108], wearing boots and long trousers or repellent, using deticking as the second line measure. Another reason to avoid ticks is that in Belgium only $30 \%$ of Lyme patients remember a bite and 35\% never develop Erythema migrans [109]. Lyme disease can be difficult to diagnose in the absence of Erythema migrans and particularly if additional symptoms are caused by co-occurring pathogens.

The analysis of the presence of pathogens in ticks might be easier than in human blood as organisms are more easily detected by PCR in ticks than in blood. Systematic surveys using ticks as sentinels could assess the prevalence of the pathogens in wildlife. Geolocation of tick and pathogen records allows integration into a more general databases such as those developed in the framework of The Vbornet [5] or the TICK MAP initiative [110] and could help fulfil the empty maps for tick and tick-borne disease occurrence in Belgium [4,6]. This study based on imperfect sampling data calls for an increased surveillance of ticks and tick-borne species at a detailed spatial scale as well as clarification of local vector status for tick species and pathogens which occur in these species. A systematic survey of ticks and associated pathogens is called for in Europe, as well as better characterisation of species interaction in the ecology of tick-borne diseases.

\section{Additional files}

Additional file 1: Detailed information available per sites of occurrence for ticks recorded in Belgium. Description: table per site with geographical coordinates in latitude-longitude and in Belgian Lambert, list of records included in the site, list of species included in the sites, literature/collection references for the sites and general quality level. Additionally to the main tab a Memo tab describes each field.

Additional file 2: Records of tick occurrence in Belgium. Description: a kmz file to open in Google Earth with 5 folders to navigate into the database. (1) Records per tick species: one point per record classified in folders by tick species, (2) Records per pathogens: one point per record classified in folders by pathogen genus then species, (3) Records per authors: one point per record classified in folders by authors, (4) Sites: one point per site with information on tick species and pathogens, (5) Records: One point per record with information available in the Additional file 1 included.

Additional file 3: Micro-organisms found locally or abroad in tick species present or potentially present in Belgium. Description: tick species, reference of the article and details on the records, discussion on pathogenicity to humans and potential transmission by tick species, and pathogenicity status as well as reference to specific articles and overall assessment of vector status.

\section{Abbreviations}

ARSIA: Association Régionale de Santé et d'Identification Animale; BLAST: Basic Local Alignment Search Tool; CCHFV: Crimean Congo Hemorrhagic Fever virus; DGZ: Dierengezonheidzorg Animal Health Care Flanders Belgium; DNA: deoxyribonucleic acid; dNTP: deoxy ribonucleotide triphosphate; IK: Issuk Kul virus; IRSIA: Institut pour l'encouragement de la recherche dans I'industrie et l'agriculture; IRSNB: Institut Royal des Sciences Naturelles de Belgique; ITS2: second Internal Transcribed Spacer 2; LIV: Looping III virus; OHFV: Omsk Hemorragic fever virus; PCR: Polymerase Chain Reaction; RLVBD: Reference Laboratory for Vector Borne Disease; SOK: Sokuluk virus; TBEV: Tick-borne Encephalitis virus; UA: University of Antwerp collection; UGENT FOREST: Ghent University, Forestry department collection; UGENT VETE: Ghent University, Faculty of Veterinary Medicine; UCLIREC: Université Catholique de Louvain Clinical and experimental research institute; WILDSCREEN: Network for disease surveillance in wildlife; WNV: West Nyle virus.

\section{Competing interests}

The authors declare that they have no competing interests.

\section{Authors' contributions}

VO: Design of the study, compilation of the record, writing up of the manuscript. MW: Organisation of data collection, tick and pathogens identification, writing up the manuscript. AL: Organisation of data collection, revising the manuscript. EC: Details on data collection, revising the manuscript. PH: Organisation of data collection, tick and pathogens identification, revising the manuscript. DH: Organisation of data collection, tick and pathogens identification, writing up the manuscript. MM: Organisation of data collection, tick and pathogens identification, revising the manuscript. JM: Organisation of data collection, revising the manuscript. ML: Details on data collection, revising the manuscript. WT: Details on data collection, revising the manuscript. LL: Details on data collection, tick and pathogens identification, revising the manuscript. TH: tick and pathogens identification, revising the manuscript. Gvl: Collected many data, tick identification, advice on manuscript design, provided expert knowledge, and revised the manuscript. All authors read and approved the final version of the manuscript.

\section{Acknowledgements}

Many thanks to Adrien Nahayo and other collaborators of the WILDSCREEN network for monitoring of diseases in wildlife and for their time and effort in collecting ticks. The authors would also like to thank Philippe Martin from the Saint-Luc hospital in Bouge Belgium, Thomas Kesteman from the UCL IREC Institute, the staff of the Royal Institute for Natural Sciences of Belgium (IRSNB) including Georges Wauthy and Léon Baert, the staff of 
GlaxoSmithKline including Yves Lobet and Pierre Voet for providing fresh records or additional details on their published records. The authors are grateful to the nature organisation NATAGORA and NATUURPUNT and particularly Wouter Vanreusel, Marc Herremans, Karin Gielen, Jean-Yves Paquet and Antoine Derouaux for providing details and numerous records of tick location. Thanks to Sophie Vanwambeke, Eva De Clercq, Sen li and Nienke Harteminck for support and raw literature. Thanks to BAYER for accepting to share their records for our research. Many thanks to the Belgian Sciences Policy Office for funding this work through the STEREO II project for Earth Observation (MULTITICK project).

\section{Author details}

'Université Catholique de Louvain, Earth and Life Institute, Georges Lemaitre climate and earth research centre, place Louis Pasteur 3, 1348, Louvain la Neuve, Belgium. ${ }^{2}$ Biodiversity department ELIB, Université Catholique de Louvain, Earth and Life Institute, 4 place Croix du sud, 1348, Louvain-la-Neuve, Belgium. ${ }^{3}$ Department of infectious and parasitic diseases, health and pathology of the wildlife, University of Liège, boulevard de Colonster 20,4000, Liège 1, Belgium. "Laboratory of Parasitology, Faculty of Veterinary Medicine, Ghent University, Salisburylaan 133 9820, Merelbeke, Belgium. ${ }^{5}$ Reference Laboratory for Vector-Borne Diseases, Queen Astrid Military Hospital, Bruynstraat 1, 1120, Brussels, Belgium. ${ }^{6}$ Evolutionary ecology group, Department of Biology, University of Antwerp, Groenenborgerlaan, 171-2020, Antwerpen, Belgium. ${ }^{7}$ Institute for Tropical Medicine, 155 nationalestraat, B2000, Antwerpen, Belgium. ${ }^{8}$ Department of Veterinary Tropical Diseases, University of Pretoria, Pretoria, South Africa. ${ }^{9}$ ARSIA, Allée des Artisans, 2 - 5590, Ciney, Belgium. ${ }^{10}$ Dierenarts Gezondheidszorg Herkauwers Veepeiler, DGZ Vlaanderen, I Hagenbroeksesteenweg 167 I, 2500, Lier, Belgium. ${ }^{11}$ Laboratory of Forestry, Department of Forest and Water Management, Ghent University, Geraardsbergsesteenweg 267, 9090, Melle-Gontrode, Ghent, Belgium. ${ }^{12}$ Laboratory of Parasitology and Pathology of Parasitic Diseases, Department of Infectious and Parasitic Diseases, Faculty of Veterinary Medicine, University of Liège, Bd de Colonster 20 B43, 4000, Liège, Belgium.

Received: 25 May 2013 Accepted: 16 June 2013

Published: 22 June 2013

\section{References}

1. Heyman P, Cochez C, Hofhuis A, Van der Giessen J, Sprong H, Porter SR, Losson B, Saegerman C, Donoso-Mantke O, Niedrig M, Papa A: A clear and present danger: tick-borne diseases in Europe. Expert Rev of Anti-Infe 2010, 8:33-50.

2. Hofhuis A, Harms M, Van der Giessen G, Sprong H, Notermans D, Van Pelt W: Ziekte van Lyme in Nederland 1994-2009: Aantal huisartsconsulten blijft toenemen. Is voorlichting en curatief beleid genoeg? Infectieziekten Bull 2010, 21:84-87.

3. Sprong $H$, Hofhuis A, Gassner F, Takken W, Jacobs F, van Vliet AJH, van Ballegooijen M, van der Giessen J, Takumi K: Circumstantial evidence for an increase in the total number and activity of Borrelia-infected Ixodes ricinus in the Netherlands. Parasit Vectors 2012, 5:294.

4. Estrada-Peña A, Farkas R, Jaenson TGT, Koenen F, Madder M, Pascucci I, Salman M, Tarrés-Call J, Jongejan F: Association of environmental traits with the geographic ranges of ticks (Acari: Ixodidae) of medical and veterinary importance in the western Palearctic. A digital data set. Experiment Appl Acarol 2013, 59(3):351-366.

5. VBORNET European network for arthropod vector surveillance for human public health. [http://www.vbornet.eu/].

6. EFSA Panel on Animal Health and Welfare (AHAW): Scientific opinion on geographic distribution of tick-borne infections and their vectors in Europe and the other regions of the Mediterranean basin. EFSA J 2010, 8(9):1723.

7. Heylen D, Tijsse E, Fonville M, Matthysen E, Sprong H: Transmission dynamics of Borrelia burgdorferi s.l. in a bird tick community. Environ Microbiol 2013, 15(2):663-673.

8. Wielinga PR, Gaasenbeek C, Fonville M, de Boer A, de Vries A, Dimmers W, Akkerhuis Op Jager G, Schouls LM, Borgsteede F, van der Giessen JWB: Longitudinal analysis of tick densities and borrelia, anaplasma, and ehrlichia infections of ixodes ricinus ticks in different habitat areas in the Netherlands. Appl Environ Microbiol 2006, 72(12):7594-7601.

9. Tekenradar.nl. The Netherlands: Publisher Wageningen University, RIVM en De Natuurkalender; 2013 [http://www.tekenradar.nl/].
10. Ducoffre G: Surveillance des maladies infectieuses par un réseau de laboratoires de microbiologie 2009. Tendances epidémiologiques 1983-2008. Belgian Institute for Public Health (ISP-WIV): Belgium; 2009 [http://www.iph. fgov.be/epidemio/epifr/plabfr/plabanfr/index09.htm. Rapport 2009].

11. Vanthomme K, Bossuyt N, Boffin N, Van Casteren V: Incidence and management of presumption of Lyme borreliosis in Belgium: recent data from the sentinel network of general practitioners. Eur J Clin Microbiol Infect Dis 2012, 31:2385-2390.

12. Stanek G, Fingerle V, Hunfeld K-P, Jaulhac B, Kaiser R, Krause A, Kristoferitsch W, O'Connell S, Ornstein K, Strle F, Gray J: Lyme borreliosis: clinical case definitions for diagnosis and management in Europe. Clin Microbiol Infect 2011, 17:69-79.

13. Claerebout E, Losson B, Cochez C, Casaert S, Dalemans AC, De Cat A, Madder M, Saegerman C, Heyman P, Lempereur L: Ticks and associated pathogens collected from dogs and cats in Belgium. Parasit Vectors 2013, 6:183.

14. Li S, Heyman P, Cochez C, Simons L, Vanwambeke SO: A multi-level analysis of the relationship between environmental factors and questing Ixodes ricinus dynamics in Belgium. Parasit Vectors 2012, 5:149.

15. Tack W, Madder M, Baeten L, Vanhellemont M, Gruwez R, Verheyen K: Local habitat and landscape affect Ixodes ricinus tick abundances in forests on poor, sandy soils. Forest Ecol Manag 2012, 265:30-36.

16. Tack W, Madder M, De Frenne P, Vanhellemont M, Gruwez R, Verheyen K: The effects of sampling method and vegetation type on the estimated abundance of Ixodes ricinus ticks in forests. Exp Appl Acarol 2011, 54:285-292.

17. Lempereur L, Lebrun M, Cuvelier P, Sépult G, Caron Y, Saegerman C, Shiels $\mathrm{B}$, Losson B: Longitudinal field study on bovine Babesia spp. and Anaplasma phagocytophilum infections during a grazing season in Belgium. Parasitol Res 2012, 110:1525-1530.

18. Kesteman T, Rossi C, Bastien P, Brouillard J, Avesani V, Olive N, Martin P, Delmée M: Prevalence and genetic heterogeneity of Borrelia burgdorferi sensu lato in Ixodes ticks in Belgium. Acta Clin Belg 2010, 65:319-322.

19. Heylen DJA, Madder M, Matthysen E: Lack of resistance against the tick Ixodes ricinus in two related passerine bird species. Int J Parasitol 2010, 40:183-191.

20. Heylen DJA, Matthysen E: Contrasting detachment strategies in two congeneric ticks (Ixodidae) parasitizing the same songbird. Parasitology 2010, 137:661-667.

21. Heylen DJA, Matthysen E: Differential virulence in two congeneric ticks infesting songbird nestlings. Parasitology 2011, 138:1011-1021.

22. Heylen DJA, Matthysen E: Experimental evidence for host preference in a tick parasitizing songbird nestlings. Oikos 2011, 120:1209-1216.

23. Linden A, Wirtgen M, Volpe S, Nahayo A, Pirson J, Paternostre J, Grégoire F: Surveillance of wildlife diseases in Belgium. Rev Épid San Anim 2011, 59-60:213-215.

24. Zahler M, Gothe R, Rinder H: Genetic evidence against a morphologically suggestive conspecificity of Dermacentor reticulatus and D. Marginatus (acari: ixodidae). Int J Parasitol 1995, 25:1413-1419.

25. Dobec M, Golubic D, Punda-Polic V, Kaeppeli F, Sievers M: Rickettsia Helvetica in dermacentor reticulatus ticks. Emerg Infect Dis 2009, 15:98-100.

26. Bigaignon G, Martin P, Tomasi JP, Gonzalez M, Lozes E, Gillion P, Fain A: La maladie de Lyme en belgique:présence du spirochète borrelia burgdorferi dans les tiques ixodes ricinus récoltées dans la région mosane. Rev Med Liege 1989, 44(15-16):489-493.

27. Fain A: Les tiques de belgique: acari, ixodoidea. Belgium: Royal Belgian Institute of Natural Sciences Press; 1990

28. Hillyard PD: Ticks of north-west Europe: keys and notes for identification of the species. London: Linnean Society of London and the Estuarine and Coastal Sciences Association, Field Studies Council; 1996

29. Rageau J: Répartition géographique et rôle pathogène des tiques (acariens: Argasidae et Ixodidae) en France. Wladomosci Parazytologiczne 1972, 43(4-6):707-719.

30. Aubert M: Contribution à l'étude du parasitisme du renard (Vulpes vulpes L.) par les Ixodidae (Acarina) dans le nord-est de la France. Acarologia 1975, 17(3):452-479.

31. Bronswijk JEMH, Garben AFM, Rijntjes RH: De teken ixodida van de beneluxlanden. The Netherlands: Wetenschappelijke mededelingen van de Koninklijke Nederlandse Natuurhistorische Vereniging; 1979.

32. Petney T, Pfaffle $M$, Skuballa J: An annoted checklist of the ticks (Acari:Ixodida) of Germany. Syst Appl Acarol 2012, 17:115-170.

33. Gern L, Rouvinez E, Toutoungi LN, Godfroid E: Transmission cycles of Borrelia burgdorferi sensu lato involving Ixodes ricinus and/or I. hexagonus 
ticks and the European hedgehog, Erinaceus europaeus, in suburban and urban areas in Switzerland. Folia Parasitol 1997, 44:309-314.

34. Cochez C, Lempereur L, Madder M, Claerebout E, Simons L, DE Wilde N, Linden A, Saegerman C, Heyman P, Losson B: Foci report on indigenous Dermacentor reticulatus populations in Belgium and a preliminary study of associated babesiosis pathogens. Med Vet Entomol 2012, 26:355-358.

35. Aeschlimann A: Ixodes ricinus, Linnée, 1758 Ixodoidea; Ixodidae: Essai préliminaire de synthèse sur la biologie de cette espèce en Suisse. Switzerland: Verlag für Recht und Gesellschaft; 1972.

36. Schöffel I, Schein E, Wittstadt U, Hentsche J: [Parasite fauna of red foxes in Berlin (West)]. Berl Munch Tierarztl Wochenschr 1991, 104:153-157.

37. Panas E, Léger N, Kretz JL, Dumesnil C: [lxodidae of the champagneArdennes region. Preliminary study]. Acarologia 1976, 28:51-55.

38. Liebisch A, Rahman MS: [Prevalence of the ticks dermacentor marginatus (sulzer, 1776) and dermacentor reticulatus (Fabricius, 1794) and their importance as vectors of diseases in Germany (author's transl)]. Tropenmed Parasitol 1976, 27:393-404.

39. Hornok S, Farkas R: Influence of biotope on the distribution and peak activity of questing ixodid ticks in Hungary. Med Vet Entomol 2009, 23:41-46.

40. Acunman K: Zecken and flussnahen biotopen in Baden-Wurttemberg. Karlsruhe Institue of Technology: Bsc Thesis; 2010.

41. Barker S, Murrell A: Systematics and evolution of ticks with a list of valid genus and species names. In Ticks biology, diseases and control. Edited by Bowman A, Nuttall P. Cambridge: Cambridge University Press; 2008:1-39.

42. Dobson ADM, Taylor JL, Randolph SE: Tick (Ixodes ricinus) abundance and seasonality at recreational sites in the UK: hazards in relation to finescale habitat types revealed by complementary sampling methods. Ticks Tick Born Dis 2011, 2:67-74

43. Arthur DR: British ticks. London: Butterworth; 1963.

44. Beaucournu J, Matile L: Contribution à l'inventaire faunistique des cavités souterraines de l'Ouest de la France.3. Liste des espèces, bibliographie. Ann Speleol 1963, 18:519-531.

45. Bown KJ, Lambin X, Telford GR, Ogden NH, Telfer S, Woldehiwet Z, Birtles RJ: Relative importance of Ixodes ricinus and Ixodes trianguliceps as vectors for Anaplasma phagocytophilum and Babesia microti in field vole (Microtus agrestis) populations. Appl Environ Microbiol 2008, 74:7118-7125.

46. Mans B, Gothe R, Neitz A: Tick toxins: perspectives on paralysis and other forms of toxicoses caused by ticks. In Ticks: biology, diseases and control. Edited by Bowman A, Nuttall P. Cambridge: Cambridge University Press; 2008:108-126.

47. Eskow E, Adelson ME, Rao RVS, Mordechai E: Evidence for disseminated Mycoplasma fermentans in New jersey residents with antecedent tick attachment and subsequent musculoskeletal symptoms. J Clin Rheumatol 2003, 9:77-87.

48. Polkowska A, Harjunpaa A, Toikkanen S, Lappalainen M, Vuento R, Vuorinen T, Kauppinen J, Flinck H, Lyytikainen O: Increased incidence of Mycoplasma pneumoniae infection in Finland, 2010-2011. Euro Surveill 2012, 17:1-4.

49. Eibach D, Casalegno J, Escuret V, Billaud G, Mekki Y, Frobert E, BouscambertDuchamp M, Lina B, Morfin F: Increased detection of Mycoplasma pneumoniae infection in children, Lyon, France, 2010 to 2011. Euro Surveill 2012, 17:1-3.

50. Bonnet S, Jouglin M, Malandrin L, Becker C, Agoulon A, L'hostis M, Chauvin A: Transstadial and transovarial persistence of Babesia divergens DNA in Ixodes ricinus ticks fed on infected blood in a new skin-feeding technique. Parasitology 2007, 134(2):197-207.

51. Bonnet S, Brisseau N, Hermouet A, Jouglin M, Chauvin A: Experimental in vitro transmission of Babesia sp. (EU1) by Ixodes ricinus. Vet Res 2009, 40:21.

52. Gray J, von Stedingk LV, Gürtelschmid M, Granström M: Transmission studies of babesia microti in ixodes ricinus ticks and gerbils. J Clin Microbiol 2002, 40(4):1259.

53. Famerée $L$, Cotteleer $C$, Antoine $H$ : La babésiose bovine en Belgique, une anthropozoonose envahissante et méconnue. Incidence des babésioses animales sur la santé humaine. Rev Med Liege 1977, 32:383-390.

54. Losson B, Mollet J, Avez F, Malaise F, Mignon B: Description de trois cas autochtones de babesiose canine (Babesia canis) en Belgique. Ann Med Vet 1999, 143:119-124.

55. Jaenson T, Talleklint L, Lundqvist L, Olsen B, Chirico J, Mejlon H: Geographical distribution, host associations, and vector roles of ticks (Acari: Ixodidae, Argasidae) in Sweden. J Med Entomol 1994, 31:240-256
56. Estrada-Peña A, Martinez JM, Sanchez Acedo C, Quilez J, Del Cacho E: Phenology of the tick, Ixodes ricinus, in its southern distribution range (central Spain). Med Vet Entomol 2004, 18:387-397.

57. Mehl R: The distribution and host relations of Norwegian ticks (Acari, Ixodides). Fauna Norvegica Serie B. Norw Journal Entomol 1983, 30:46-51.

58. Sevcik M, Kristofik J, Uhrin M, Benda P: New records of ticks (Acari: Ixodidae) parasiting on bats in Slovakia. Vespertilio 2010, 13-14:139-147.

59. Fain A, Vangeluwe $D$, Degreef $M$, Wauthy $G$ : Observations on mites inhabiting nests of Bubo bubo (L.) (Strigigformes, Strigidae) in Belgium. Bel J Zool 1993, 123(1):3-26.

60. Kurtenbach K, Peacey M, Rijpkema SGT, Hoodless AN, Nuttall PA, Randolph SE: Differential transmission of the genospecies of Borrelia burgdorferi sensu lato by game birds and small rodents in England. Appl Environ Microbiol 1998, 64:1169-1174.

61. Marsot M, Henry P-Y, Vourc'h G, Gasqui P, Ferquel E, Laignel J, Grysan M, Chapuis J-L: Which forest bird species are the main hosts of the tick, Ixodes ricinus, the vector of Borrelia burgdorferi sensu lato, during the breeding season? Int J Parasitol 2012, 42:781-788.

62. Herrmann C, Voordouw MJ, Gern L: Ixodes ricinus infected with the causative agent of Lyme disease, Borrelia burgdorferi sensu lato, have higher energy reserves. Int J Parasitol 2013, 43(6):477-483.

63. Perret J-L, Guerin PM, Diehl PA, Vlimant M, Gern L: Darkness induces mobility, and saturation deficit limits questing duration, in the tick Ixodes ricinus. J Exp Biol 2003, 206:1809-1815.

64. Crooks E, Randolph SE: Walking by Ixodes ricinus ticks: Intrinsic and extrinsic factors determine the attraction of moisture or host odour. J Experiment Biol 2006, 209(11):2138-2142.

65. Gern L, Toutoungi LN, Hu CM, Aeschlimann A: Ixodes (Pholeoixodes) hexagonus, an efficient vector of Borrelia burgdorferi in the laboratory. Med Vet Entomol 1991, 5:431-435.

66. Estrada-Peña A, Oteo JA, Estrada-Peña R, Gortázar C, Osácar JJ, Moreno JA, Castellá J: Borrelia burgdorferi sensu lato in ticks (Acari: Ixodidae) from two different foci in Spain. Exp Appl Acarol 1995, 19:173-180.

67. Matuschka FR, Richter D, Fischer P, Spielman A: Nocturnal detachment of the tick Ixodes hexagonus from nocturnally active hosts. Med Vet Entomol 1990, 4:415-420.

68. Pfäffle M, Petney T, Skuballa J, Taraschewski H: Comparative population dynamics of a generalist (Ixodes ricinus) and specialist tick (I. hexagonus) species from European hedgehogs. Exp Appl Acarol 2011, 54:151-164.

69. Estrada-Peña A, Jongejan F: Ticks feeding on humans: a review of records on human-biting Ixodoidea with special reference to pathogen transmission. Exp Appl Acarol 1999, 23:685-715.

70. Movila A, Gatewood A, Toderas I, Duca M, Papero M, Uspenskaia I, Conovalov J, Fish D: Prevalence of Borrelia burgdorferi sensu lato in Ixodes ricinus and I. lividus ticks collected from wild birds in the Republic of Moldova. Int J Med Microbiol 2008, 298(Suppl 1):149-153.

71. Monks D, Fisher M, Forbes NA: Ixodes frontalis and avian tick-related syndrome in the United Kingdom. J Small Anim Pract 2006, 47:451-455.

72. Gilot B, Beaucournu JC, Chastel C: Collecte «au drapeau» et fixation sur I' homme d'Ixodes (Trichotoixodes) frontalis (Panzer, 1795). Parasite 1997, 4(2):197-199.

73. Špitalska E, Literak I, Kocianova E, Taragelova V: The importance of ixodes arboricola in transmission of rickettsia spp., anaplasma phagocytophilum, and borrelia burgdorferi sensu lato in the Czech republic, central Europe. Vector Borne Zoonotic Dis 2011, 11:1235-1241.

74. Ulmanen I, Saikku P, Vikberg P, Sorjonen J: Ixodes lividus (acari) in sand martin colonies in fennoscandia. Oikos 1977, 28:20.

75. Uchikawa K, Sato A: The occurrence of Argas japonicus and ixodes lividus in Nagano prefecture, Japan (ixodoidea: argasidae; ixodidae). J Med Entomol 1969, 6:95-97.

76. Doby JM, Bigaignon G, Launay H, Costil C, Lorvellec O: Presence of borrelia burgdorferi, agent of tick spirochaetosis, in ixodes (exopalpiger) trianguliceps Birula, 1895 and ixodes (ixodes) acuminatus Neumann, 1901 (acari: ixodidae) and in ctenophthalmus baeticus arvernus Jordan, 1931 and megabothris turbidus (Rothschild, 1909) (insecta: siphonaptera), ectoparasites of small mammals in forests in western France. Bull Soc Fr Parasitol 1990, 8:311-322.

77. Doby JM, Bigaignon G, Aubert M, Imbert G: Ectoparasites du renard et borreliose de Lyme. Recherche de borrelia burgdorferi chez les tiques ixodidae et insectes siphonaptera. Bull Soc Fr Parasitol 1991, 9:279-288. 
78. Hubbard MJ, Baker AS, Cann KJ: Distribution of borrelia burgdorferi s.l. Spirochaete DNA in British ticks (argasidae and ixodidae) since the 19th century, assessed by PCR. Med Vet Entomol 1998, 12:89-97.

79. Gilot B, Aubert M: Les Ixodidae (acarines, ixodoidea) parasites de carnivores sauvages dans les alpes françaises et leur avant-pays. Acarologia 1985, 26:215-233.

80. Ogden NH, Cripps P, Davison CC, Owen G, Parry JM, Timms BJ, Forbes AB: The ixodid tick species attaching to domestic dogs and cats in Great Britain and Ireland. Med Vet Entomol 2000, 14:332-338.

81. Smith M: The life history of Ixodes canisuga (Johnston 1849) under laboratory conditions. Ann Trop Med Parasitol 1972, 66:281-286.

82. Graf J, Mermod C, Aeschlimann A: Nouvelles données concernant la distribution, l'écologie et la biologie d'Ixodes (Exopalpiger) trianguliceps (Birula, 1895) en Suisse (Ixodoidea, Ixodidae). Bull Soc Neuchat Sci Nat 1979, 102:55-68

83. Aeschlimann A, Büttiker W, Diehl PA, Eichenberger G, Immler R, Weiss N: [Presence of Ixodes trianguliceps (Birula, 1895) and Ixodes apronophorus (Schulze, 1924) in Switzerland (Ixodoidea; Ixodidae)]. Rev Suisse Zool 1970, 77:527-536.

84. Boyard C, Vourc'h G, Barnouin J: The relationships between Ixodes ricinus and small mammal species at the woodland-pasture interface. Exp Appl Acarol 2008, 44:61-76.

85. Pisanu B, Marsot M, Marmet J, Chapuis J-L, Réale D, Vourc'h G: Introduced Siberian chipmunks are more heavily infested by ixodid ticks. Int $J$ Parasitol 2010, 40(11):1277-1283.

86. Dantas-Torres F: Biology and ecology of the brown dog tick, rhipicephalus sanguineus. Parasit Vectors 2010, 3:26.

87. Aeschlimann A, Buttiker W: Importation de tiques en Suisse (Acarina: Ixodoidea). Bull Soc Entomol Suisse 1975, 48(1-2):69-75.

88. Hoffmann G: Die Braune hundezecke (rhipicephalus sanguineus L.) in Berlin (west). epizootologische untersuchungen unter einschaltung von massenmedien. Bundesgesundheitsblatt 1981, 24:153-163.

89. Péter O, Burgdorfer W, Aeschlimann A, Chatelanat P: Rickettsia conorii isolated from Rhipicephalus sanguineus introduced into Switzerland on a pet dog. Z Parasitenkd 1984, 70:265-270.

90. Sibomana G, Geerts S, De Vries T: [Establishment of Rhipicephalus sanguineus (Latreille, 1806) inside houses in Belgium]. Ann Soc Belg Med Trop 1986, 66:79-81.

91. Gray JS, Dautel H, Estrada-Peña A, Kahl O, Lindgren E: Effects of climate change on ticks and tick-borne diseases in Europe. Interdiscip Perspect Infect Dis 2009, 2009:593232.

92. Campbell BS, Bowles DE: Human tick bite records in a United States air force population, 1989-1992: implications for tick-borne disease risk. J Wilderness Med 1994, 5:405-412.

93. Hemmersbach-Miller M, Parola P, Brouqui P, Raoult D: A 51-year-old homeless man who died in Marseille, southern France. Clin Infect Dis 2004, 38:1412-1493.

94. Parola P, Socolovschi C, Jeanjean L, Bitam I, Fournier P-E, Sotto A, Labauge $P$, Raoult D: Warmer weather linked to tick attack and emergence of severe rickettsioses. PLOS Negl Trop Dis 2008, 2:e338

95. Estrada-Peña A, Bouattour A, Camicas J-L, Walker AR: Ticks of domestic animals in the Mediterranean region: a guide to identification of species. Zaragoza: University of Zaragoza; 2004.

96. Blanc J, Camino Pietros J: Epidemiological and experimental studies on Boutonneuse fever done at the Pasteur institute in Athens. Arch Inst Pasteur Tunis 1932, 20:343-394.

97. Hoogstraal H: Argasid and Nuttalliellid ticks as parasites and vectors. Adv Parasitol 1985, 24:135-238.

98. Dautel H, Scheurer S, Kahl O: The pigeon tick (Argas reflexus): its biology, ecology, and epidemiological aspects. Zbl Bakt 1999, 289(5-7):745-753.

99. Dautel H, Kahl O, Knülle W: The soft tick Argas reflexus (F.) (Acari, Argasidae) in urban environments and its medical significance in Berlin (West). J Appl Entomol 1991, 111:380-390

100. Hilger C, Bessot J-C, Hutt N, Grigioni F, De Blay F, Pauli G, Hentges F: IgEmediated anaphylaxis caused by bites of the pigeon tick Argas reflexus: cloning and expression of the major allergen Arg r 1. J Allergy Clin Immunol 2005, 115:617-622.

101. Evans NJ, Bown K, Timofte D, Simpson VR, Birtles RJ: Fatal Borreliosis in bat caused by relapsing fever spirochete, United Kingdom. Emerging Infect Dis 2009, 15:1331-1333.
102. Beaucournu J: Contribution à la connaissance de la biologie $\mathrm{d}^{\prime}$ Ixodes (Eschatocephalus) Vespertilionis Koch 1844 et d'Ixodes (Pomerantzevella) simplex Neumann 1906 (Acarina, Ixodoidea), parasites des chiroptères. Ann speleol 1967, 22:543-580.

103. Obsomer V, Titeux N, Duveiller G, Vancutsem C, Pekel J-F, Ceccato P, Connor S, Coosemans M: From Anopheles to spatial surveillance: a roadmap through a multidisciplinary challenge. In Anopheles mosquitoes New insights into malaria vectors. Edited by Manguin S. Rijeka, Croatia: InTech Publisher; 2013. in press.

104. Daniel MJ, Kola Zeman R: GIS tools for tick and tick-borne disease occurrence. Parasitology 2004, 129:329-352.

105. Sinka ME, Bangs MJ, Manguin S, Chareonviriyaphap T, Patil AP, Temperley WH, Gething PW, Elyazar IRF, Kabaria CW, Harbach RE, Hay SI: The dominant anopheles vectors of human malaria in the Asia-pacific region: occurrence data, distribution maps and bionomic précis. Parasit Vectors 2011, 4:89.

106. Obsomer V, Defourny P, Coosemans M: Predicted Distribution of major malaria vectors belonging to the anopheles dirus complex in Asia: ecological niche and environmental influences. PLoS One 2012, 7(11): e50475.

107. Charrel RN, Attoui H, Butenko AM, Clegg AMJC, Deubel V, Frolova TV, Gould EA, Gritsun TS, Heinz FX, Labuda M, Lashkevich VA, Loktev V, Lundkvist A, Lvov DV, Mandl CW, Niedrig M, Papa A, Petrov VS, Plyusnin A, Randolph S, Suss J, Zlobin VI, de Lamballerie X: Tick-borne virus diseases of human interest in Europe. Clin Microbiol Infect 2004, 10:1040-1055.

108. Trotter WR: Is bracken a health hazard? Lancet 1990, 336:1563-1565.

109. Bigaignon G, Tomasi JP, Goubau P, Martin P, Pierard D, Sindic CJ, Dupuis M, Marcelis L, Degreef $H$, Willocx D: A clinical and sero-epidemiological study of 190 Belgian patients suffering from Lyme borreliosis. Acta Clin Belg 1989, 44:174-181.

110. Walter Reed biosystematics unit TICKMAP. USA: The Walter Reed Biosystematics Unit; accessed in April 2013. http://www.tickmap.org/index.htm.

doi:10.1186/1756-3305-6-190

Cite this article as: Obsomer et al:: Spatial disaggregation of tick occurrence and ecology at a local scale as a preliminary step for spatial surveillance of tick-borne diseases: general framework and health implications in Belgium. Parasites \& Vectors 2013 6:190.

\section{Submit your next manuscript to BioMed Central and take full advantage of:}

- Convenient online submission

- Thorough peer review

- No space constraints or color figure charges

- Immediate publication on acceptance

- Inclusion in PubMed, CAS, Scopus and Google Scholar

- Research which is freely available for redistribution 